
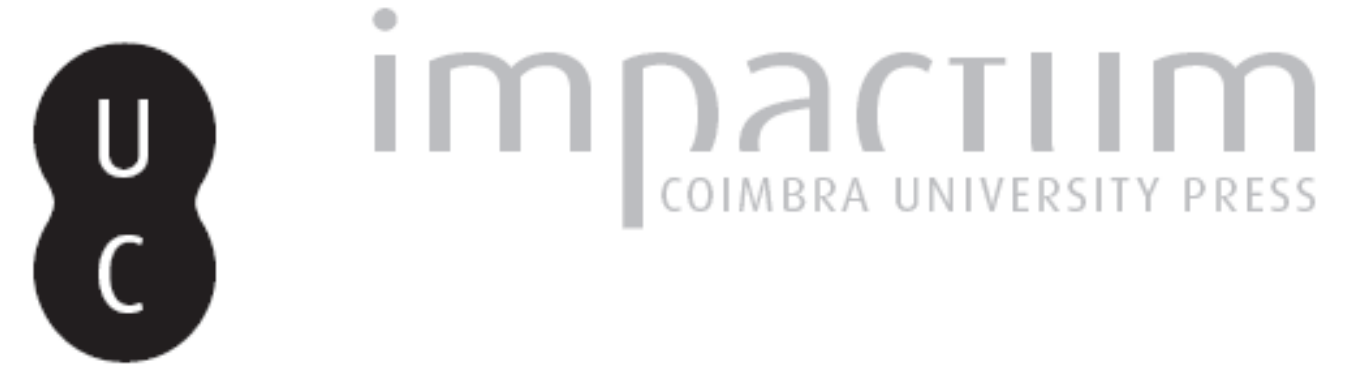

\title{
As wrong actions no início da vida (wrongful conception, wrongful birth e wrongful life) e a responsabilidade médica
}
Autor(es):
Raposo, Vera Lúcia
Publicado por: Imprensa da Universidade de Coimbra
URL
persistente:
URI:http://hdl.handle.net/10316.2/33210
DOI:
DOI:http://dx.doi.org/10.14195/1647-8630_21_4

Accessed : $\quad$ 26-Apr-2023 11:31:46

A navegação consulta e descarregamento dos títulos inseridos nas Bibliotecas Digitais UC Digitalis, UC Pombalina e UC Impactum, pressupõem a aceitação plena e sem reservas dos Termos e Condições de Uso destas Bibliotecas Digitais, disponíveis em https://digitalis.uc.pt/pt-pt/termos.

Conforme exposto nos referidos Termos e Condições de Uso, o descarregamento de títulos de acesso restrito requer uma licença válida de autorização devendo o utilizador aceder ao(s) documento(s) a partir de um endereço de IP da instituição detentora da supramencionada licença.

Ao utilizador é apenas permitido o descarregamento para uso pessoal, pelo que o emprego do(s) título(s) descarregado(s) para outro fim, designadamente comercial, carece de autorização do respetivo autor ou editor da obra.

Na medida em que todas as obras da UC Digitalis se encontram protegidas pelo Código do Direito de Autor e Direitos Conexos e demais legislação aplicável, toda a cópia, parcial ou total, deste documento, nos casos em que é legalmente admitida, deverá conter ou fazer-se acompanhar por este aviso.

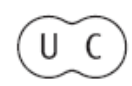




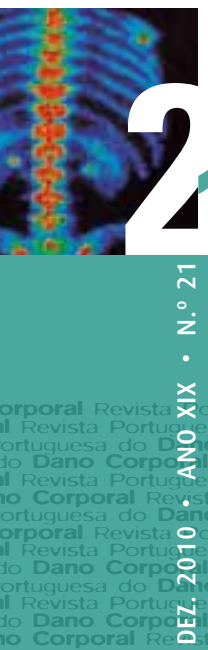

REVISTA PORTUGUESA

do

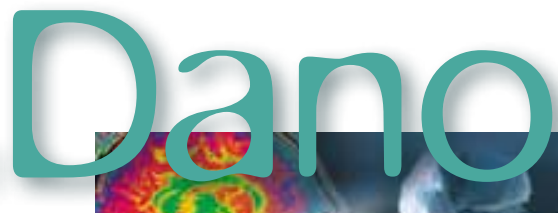

$\dot{z}$

$\dot{x}$

$\frac{x}{x}$

o. corporal Corporal Revista Portuguesa do Dano Corporal

Z

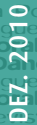

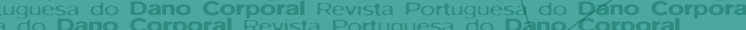

Revista Portuguesa do Dano Corporal Revista Rortuguesa do Dano Corporal

Sa do Dano Corporal Revista Portuguesa do Dano Corporal Revista Portuguesł do Dano Corporal

Portuguesa do Dano Corporal Revista portuguesta do Dano Corporal 


\section{As wrong actions no início da vida (wrongful conception, wrongful birth e wrongful life) e a responsabilidade médica}

Vera Lúcia Raposo ${ }^{1}$

\section{Wrongful life actions}

As wrongful life actions ${ }^{2}$ surgem quando uma criança nasce mal-formada e pretende reagir contra quem deu azo ao nascimento, ainda que não tenha provocado directamente a malformação. As acções de wrongful life são sempre interpostas pela criança (ou por outrem em seu nome, dado que muitas vezes falamos de um menor e/ou incapaz) nascida nestas condições, e podem

\footnotetext{
Assistente da Faculdade de Direito da Universidade de Coimbra; Advogada.

2 R. Lee AKAZAKI, "Wrongful Birth"..."; Fernando ARAÚJO, A Procriação Assistida..., p. 84/113; Virginie BONNINGUE, Naissance..., p. 65/106; Karen CAPEN, "New Prenatal Screening...”, p. 734 ss.; Kristen CAREY, “Wrongful Life...”, p. 1 ss.; Philippe COPPENS, "Du Préjudice d'Être Né?”, p. 82 ss.; João Álvaro DIAS, Procriação Assistida e Responsabilidade Médica, p. 480/605; Roger DWORKIN, Limits..., p. 86 ss.; Attilio GUARNERI, "Nascita del Figlio Malformado...", p. 847 ss.; John HARRIS, Clones..., p. 99/119; Wendy HENSEL, "The Disabling Impact...", p. 141 ss.; Nancy JECKER, "The Ascription of Rights...", p. 149 ss.; Fernando Pinto MONTEIRO, "Direito à Não Existência...", p. 131 ss.; Anne MORRIS, Severine SAINTIER, "To Be or Not to Be...", p. 167 ss.; Warwick NEVILLE, Buddhima LOKUGE, "Wrongful Life Claims...", p. 558 ss.; André Gonçalves PEREIRA, O Consentimento Informado..., p. 387 ss.; Carlos Alberto da Mota PINTO, Teoria Geral do Direito Civil, p. 217/220; Paulo Mota PINTO, "Indemnização...”, p. 5 ss.; Amos SHAPIRA, “Wrongful Life...", p. 369 ss.; Seana Valentine SHIFFRIN, "Wrongful Life...”, p. 117 ss.; R. SIMONE, "Procreazione e Danno...", p.1149 ss.; Carel STOLKER, "Wrongful Life...", p. 521 ss.; Dean STRETTON, "The Birth Torts...", p. 348/350, 352/364; Marta Nunes VICENTE (“Algumas Reflexões...”, p. 117 ss.; "Wrongful Birth/Wrongful Life Claims", at http://www.tresscox.com.au/file/document/ resource/32/Wrongful\%20Birth\%20\&\%20Wrongful\%20Life\%20Claims.pdf.

Uma distinção entre estas acções e as outras wrong actions em Philippe COPPENS, "Du Préjudice d'Être Né?”, p. 82 ss.; Jean-Yves GOFFI, "La Notion de Vie Préjudiciable...", p. 75/77; Paulo Mota PINTO, “Indemnização...”, p. 5/7.

Para uma crítica às denominações adoptadas, Fernando ARAÚJO, A Procriação Assistida..., p. 96, 100 .
} 
dirigir-se contra os médicos e instituição hospitalar e mesmo - sendo esta a hipótese mais controvertida - contra os pais.

Explicitemos melhor estes cenários.

Os processos de wrongful life podem ser dirigidos contra aquele que deveria informar os progenitores da situação do nascituro e não o fez, nomeadamente o médico que falhou no diagnóstico pré-natal ou no diagnóstico genético pré-implantatório ${ }^{3}$.

Neste caso poderão os pais da criança apresentar dois pedidos de indemnização: um em seu nome próprio, pelo danos que advêm da circunstância de ter um filho com animalidade tão gravosas (mas nesse caso estaremos perante um processo de wrongful birth); outro em nome da própria criança, pelo facto de esta ter nascido com semelhante doença ou anomalia (a wrongful live propriamente dita).

No pedido contra o médico é alegado o facto de não ter impedido a concepção, ou ter omitido informação acerca da deficiência ou malformação, ou ter transferido para o útero embriões fertilizados in vitro que eram portadores de doença ou deficiência. Assim se distinguem estas acções daqueles outros casos em que se actua contra o responsável por um dano físico causado aos progenitores - em regra, causados à mãe - e que a posteriori se veio a reflectir nos futuros filhos, estejam estes já gerados à data do dano ${ }^{4}$ ou ainda não ${ }^{5}$.

3 Usualmente a falha resulta da violação de leges artis (José Francisco de Faria COSTA, O Perigo em Direito Penal, p. 529, 532; Sónia FIDALGO, Responsabilidade Penal..., p. 71 ss.) dando assim origem a uma situação de responsabilidade médica (Conceição CUNHA, "Algumas Considerações...", p. 809/854; Álvaro DIAS, Procriação Assistida e Responsabilidade Médica...; Jorge de Figueiredo DIAS, Sinde MONTEIRO, Responsabilidade Médica em Portugal; FRANCO CAIADO GUERREIRO E ASSOCIADOS, Guia da Responsabilidade dos Médicos...; M. GÓMEZ JARA, La Responsabilidad ...; J. M. Martins NUNES, Da Responsabilidade...; André Gonçalves PEREIRA, O Consentimento Informado...; Rute Teixeira PEDRO, A Responsabilidade Civil do Médico; Álvaro da Cunha Rodrigues, "Reflexões...", p. 161/252. Imagine-se que o médico não efectuou os meios de diagnóstico necessários, o que o faz incorrer numa responsabilidade por omissão. Quanto à questão da dicotomia obrigação de meios/ obrigação de resultados na responsabilidade médica, Rute Teixeira PEDRO, A Responsabilidade Civil do Médico, p. 98/102; Álvaro da Cunha Rodrigues, "Reflexões...", p. 67 ss. Sobre a responsabilidade civil médica nesta específica matéria, Amélia COSTA, Perspectiva Jurídica de um Acto de Amor..., p. 135 ss.; João Álvaro DIAS, Procriação Assistida e Responsabilidade Médica.

4 Caso Watt v. Rama [1972] V.R. 353, Supreme Court of Victoria, Australia. O caso desenrolou-se nestes termos: o autor sofrera danos enquanto se encontrava ainda no ventre materno devido a um acidente de que a mãe havia sido vítima, causado pelo réu. Embora este argumentasse que não poderia ser responsabilizado por danos causados a uma (ainda) não-pessoa o tribunal decidiu em sentido contrário, bastando-se com o facto de o embrião ter vindo a originar uma pessoa, configurando a chamada "born alive rule". Sobre esta regra vide Pascal KASIMBA, "IVF Regulation...", p. 157 ss.

5 Por exemplo, acções que tiveram lugar sobre a mulher antes de esta engravidar, mas que se repercutiram na sua função reprodutiva, motivadas por tratamentos médicos ou pela exposição a materiais radioactivos ou substâncias tóxicas. 
Mas, como já ficou referido, esta acção pode também ser dirigida contra os pais, invocando-se o facto de estes terem prosseguido com a gestação não obstante estarem a par da doença, reivindicação esta que se funda num (ainda muito discutido) dever parental de evitar o nascimento de uma criança em tais condições ${ }^{6}$. Alguns tribunais têm vindo a reconhecer a existência de um dever, a cargos dos pais, de abortarem fetos mal-formados sob pena de actuarem mediante negligência.

A progressiva aceitação jurisprudencial deste tipo de acções prende-se com a consciencialização do crescente número de riscos envolvidos nas novas tecnologias, bem como com o movimento de liberalização que tem marcado os regimes sobre o aborto um pouco por todo o lado, revelando progressivamente uma cada vez maior aceitação legal do poder dos pais escolherem quando e como terão os seus filhos.

Embora até à data os processos de wrongful life se insiram no contexto de uma reprodução sexual, supomos que passarão a ser muito frequentes nos casos de procriação medicamente assistida (PMA), sobretudo quando teve lugar um DGPI (suponha-se, por exemplo, que o médico não informou os pais de que os embriões padeciam de determinadas anomalias, pelo que estes autorizaram a sua transferência).

Ou seja, o que acima se disse a propósito da wrongful life pode ser transposto, mutadis mutandis, para os casos de DGPI em que o médico não detectou a anomalia embrionária e, por conseguinte, procedeu à sua transferência, ou a detectou e informou os pais mas, ainda assim, estes optaram pela transferência. Com a particularidade de que nestes casos nem sequer se levanta o óbice de se interromper uma gestação porque esta ainda se não iniciou.

\section{Wrongful birth actions}

Nos casos de wrongful birth ${ }^{7}$ o circunstancialismo é o mesmo da figura anterior, com a diferença de que neste segundo a acção é movida pelos pais, em seu próprio nome, contra o médico, pelo facto de os ter privado de um consentimento informado que eventualmente poderia ter levado à interrupção

\footnotetext{
6 "As a secular moral issue, this view appears implausible if the future of the child is such that harms do not outweigh benefits. One will on balance not have armed that future person by bringing it into existence. If it is reasonable for the parents to assume that there will be a favourable balance of goods over harms to the child, procreation would appear morally justified as long as the child did not constitute an unagreed upon to others". Cfr. Tristram H. ENGELHARDT, The Foundations of Bioethics, p. 258

7 Dean STRETTON, “The Birth Torts...", p. 320, 321; 331/347.
} 
da gravidez. Este cenário ocorre ou porque o médico não afectou os exames pertinentes, ou porque os interpretou erroneamente, ou porque não comunicou os resultados. Já se vê que o desenlace destes processos depende largamente da forma como se concebam as obrigações dos profissionais de saúde no que respeita às informações aos pacientes, isto é, quais os factores de risco que devem ser comunicados e se mesmo factores improváveis o devem ser ${ }^{8}$.

Muitas vezes a fundamentação é a mesma que encontrámos nas acções de wrongful life, mas enquanto aquelas são interpostas pelo filho, estas são-no pelos pais, sendo que muitas vezes ambas acções surgem associadas num mesmo processo ${ }^{9}$, embora as duas pretensões não tenham necessariamente que coexistir ${ }^{10}$.

Os pais requerem uma indemnização pelos danos morais e patrimoniais resultantes do nascimento de um filho portador de deficiências graves. Alegam que se houvessem sido avisados dos perigos inerentes à doença de que são portadores (doença de Tay-Sachs, por exemplo) teriam preferido não conceber; ou que se tivesse sido informado da doença que o embrião/feto desenvolveu durante a gestação (trisomia 21, por exemplo) teriam optado por interromper a gravidez. Como se vê, a obrigação de informação médica pode actuar em dois momentos distintos: antes ou depois de conceber. No primeiro caso fala-se de um erro no diagnóstico pré-concepcional; no segundo, em erro no diagnóstico pré-natal ${ }^{11}$.

Têm surgido várias interrogações quanto a pedidos de indemnização de wrongful birth por parte de progenitores que teriam seguido avante com a gravidez, não obstante o aborto poder ter sido uma opção ${ }^{12}$.

8 Jean-Yves GOFFI, “La Notion de Vie Préjudiciable...", p. 77.

9 Caso Berman v. Allan N.J. 421 (1979). Neste caso a acção de wrongful life foi rejeitada pelo Tribunal ("One of the most deeply held beliefs of our society is that life - whether experienced with or without a major physical handicap - is more precious than non-life"), mas a de wrongful birth foi acolhida e satisfeita. Curiosamente, e a propósito desta segunda reivindicação, tomou uma opção que nos parece estranha: negou a indemnização pelos danos patrimoniais que derivam da educação de uma criança seriamente deficiente, mas atribuiu uma compensação pelos danos morais resultantes da angústia sofrida pelo pais em virtude de a sua filha ter síndrome de Down. Uma vez que a recusa da indemnização patrimonial se fundou no amor e na alegria que qualquer criança sempre aporta, mal se compreende que, a esta luz, tenha sido atribuída a compensação por danos morais.

10 Sobre isto, Bonnie STEINBOCK, “The Logical Case...”, p. 15/20.

11 Em regra reportamo-nos a uma gravidez já iniciada, pelo que a alternativa seria o aborto, mas podemos igualmente imputar esta responsabilidade a um periodo pré-concepcional, quando a alternativa seria o uso de métodos anti-concepcionais.

12 No Canadá o "comportamento alternativo" dos pais tem sido discutido em várias decisões: Arndt v. Smith, [1997] 2 S.C.R. 539 (Supreme Court of Canada); Mickle v. Salvation Army Grace Hospital [1998] OJ 4683 (QL) (Ont Gen Div) (R. Lee AKAZAKI, "Wrongful Birth"..."). No caso Emeh (Emeh v. Kensington and Chelsea and Westminster Area Health Authority, [1985] 
Marta Nunes Vicente ${ }^{13}$ não questiona se deve existir ou não indemnização (pois entende que será sempre de existir, porque o que está em causa não é a "possibilidade da pessoa se decidir", mas "a faculdade da pessoa se decidir numa direcção ou em sentido diferente do anterior"), mas defende que o respectivo montante variará "na medida da certeza que haja sobre o comportamento que a mãe ditaria para si própria", caso os médicos tivessem sido diligentes e os pais houvessem sido informados do estado de saúde do nascituro. Esta sua posição funda-se na teoria da "perde de chance", desenvolvida pela jurisprudência francesa, segundo a qual o valor da indemnização será tanto maior quanto mais elevada a certeza de realização de um determinado evento, isto é, depende do grau de violação do direito.

Paulo Mota Pinto ${ }^{14}$ dá-nos conta que a jurisprudência alemã, confrontada com casos de falta de informação ou errónea informação, faz funcionar a favor do credor da informação a presunção de que se teria comportado de forma adequada tendo em conta o conteúdo da informação (no caso, que os pais teriam optado por abortar caso soubessem da deficiência do filho). Se bem percebemos, o autor admite a indemnização em qualquer das hipóteses, mas quando se prove que os pais teriam interrompido a gravidez defende que deveriam ser indemnizados, não apenas pelo custo acrescido da criança deficiente, mas por todas as despesas derivadas do sustento e educação de um filho.

Temos dúvidas de que o sucesso desta reivindicação exija que se faça prova de que os pais teriam abortado caso tivessem sido devidamente informados. Não tanto pela dificuldade de semelhante prova, mas porque cremos que neste caso o dano radica, não apenas no nascimento de uma criança doente, mas também na impossibilidade de exercer uma escolha reprodutiva ${ }^{15}$ ou na violação do seu direito à informação ${ }^{16}$.

1 QB 1012; [1984] 3 All ER 1044 (CA)) o tribunal rejeitou a pretensão de indemnização da mulher precisamente pelo facto de ela não ter abortado quando teve a oportunidade, embora esta decisão tenha sido rejeitada pelo Court of Appeal.

13 Marta Nunes VICENTE, "Algumas Reflexões...", p. 122, 123.

14 Paulo Mota PINTO, “Indemnização...", p. 15, 22.

15 Colocando a tónica nesta impossibilidade, Muriel Fabre-Magnan, citada em Anne-Claire MULLER, "L'Affaire Perruche...", p. 27.

A decisão de abortar ou não apenas pode ser tomada quando os pais, mais correctamente, a mulher, se defronta com essa situação. Até que a hipótese da malformação do nascituro se torne num facto real não é possível termos qualquer certeza, ou exigirmos qualquer certeza, do comportamento materno (as mesmas reflexões a propósito do acesso ao diagnóstico pré-natal e da subsequente decisão de abortar em Guilherme de OLIVEIRA, "O Direito...", p. 222/224).

16 Qual o intuito deste dever de informação? Manuel Carneiro da FRADA ("A Própria Vida como Dano...") afasta terminantemente que este dever se destine a possibilitar à mãe a prática do aborto, mas sim a permitir uma adequada terapia da criança. 


\section{Wrongful conception actions}

Nos processos de wrongful pregnancy ou wrongful conception ${ }^{17}$ o dano consiste na concepção de uma criança em situações nas quais era supostamente garantido tal não acontecer, em virtude de uma interrupção da gravidez mal sucedida, defeitos do método anticoncepcional, uma esterilização mal efectuada $^{18}$, em suma, os casos em que se viola o que por vezes se chama de "direito dos pais ao planeamento familiar" ou direito à não reprodução.

Neste caso quem tem legitimidade para requerer a indemnização são os próprios pais e não a criança, para a qual não houve qualquer dano (referimo-nos a crianças que nasceram sãs). Ou seja, consiste no pedido de responsabilidade a quem se havia comprometido a evitar a concepção de uma criança, pelo que os queixosos pedem uma indemnização correspondente aos custos daqui decorrentes: subsequentes procedimentos médicos, despesas derivadas da educação do filho, em casos especiais, eventualmente, danos morais ${ }^{19}$. Mais uma vez, o dano não é a criança, mas a anulação da decisão reprodutiva tomada pelos pais.

Em certa medida a wrongful conception suscita ainda mais controvérsia do que a wrongful life, porquanto tradicionalmente se entende que o nascimento de uma criança - sobretudo se saudável, como no caso - é sempre uma bênção, nunca um dano jurídico. Além do mais há quem rejeite que a recusa de ter filhos seja um direito. Mas a isto respondeu de forma paradigmática, em 1971, o Michigan Court of Appeal: "contraceptives are used to prevent the birth of healthy children. To say that for reasons of public policy contraceptive failure can result in no damage as a matter of law ignores the fact that tens millions of persons use contraceptives daily to avoid the very result which the defendant would have us say is always a benefit, never a detriment. Those tens of millions of persons, by their conduct, express the sense of the community" ${ }^{\prime 2}$.

17 Virginie BONNINGUE, Naissance..., p. 15/64.

18 Paulo Mota PINTO (“Indemnização...", p. 5) insere nesta categoria os casos em que os pais têm um filho com uma deficiência genética porque não foram correctamente informados dos riscos genéticos associados, mas cremos que esta é antes uma hipótese de wrongful birth, dado que na wrongful conception o único dano é um nascimento indesejado, não a deficiência, como o autor parece reconhecer mais à frente (p. 6), ao distinguir o "dano do planeamento familiar" e o dano resultante de uma deficiência da criança nascida.

19 Sobre estes danos, Virginie BONNINGUE, Naissance..., p. 21/25.

20 Case Troppi v. Scarf (1971) 187 NW 2d 511 (Mich. CA), citado por Bernard DICKENS, "Wrongful Birth...", p. 83. 


\section{Tendências jurisprudenciais}

\subsection{A jurisprudência norte-americana}

Curiosamente, o primeiro processo de wrongful life - que surgiu nos EUA, na década de 60 - nada tinha a ver com os actuais. É que a criança nasceu de perfeita saúde, com o único óbice de ser filho de mãe solteira, já que o pai abandonara a mãe durante a gravidez. Por conseguinte, intentou uma acção contra o pai por envolver o seu nascimento em ilegitimidade jurídica. O Tribunal recusou a pretensão do requerente, sob pena de os tribunais serem inundados com milhares de processos por parte de pessoas que nasceram em condições que consideravam desfavoráveis ${ }^{21}$.

Porém, dentro do leque de processos de wrongful life tem cabido todo o tipo de pretensões, como a do filho ilegítimo que intentou uma acção contra o pai, no estado americano de Illinois, devido ao dano sofrido em função do estatuto de ilegitimidade (pretensão que não tem qualquer razoabilidade em Portugal, mas adquire algum significado naquele ordenamento jurídico, onde o referido estatuto funcionava como impedimento para um cargo político). Todavia, a pretensão não teve sucesso. Diferentemente, num outro processo de wrongful live onde a criança intentou com êxito uma acção contra um hospital de doenças mentais onde a sua mãe havia sido violada por um internado foi-lhe dada satisfação ${ }^{22}$.

Paulatinamente outros casos foram surgindo na jurisprudência norteamericana e é neste sistema jurídico que os encontramos em maior número e também onde têm obtido mais acolhimento, não obstante algumas leis estaduais terem expressamente excluído que o nascimento ou a possibilidade de abortar fossem qualificados como facto danoso.

Foi também no âmbito da common law ${ }^{23}$ que nasceram as pretensões de wrongful birth, mais propriamente num tribunal de New Jersey, no ano de $1967^{24}$, quando uma mulher apresentou ao tribunal um pedido de indemnização contra o médico que não a informou dos riscos que uma rubéola no início da gravidez poderia acarrear - e efectivamente no caso assim sucedeu - para o feto (embora o aborto fosse ilegal no estado de New Jersey não o

${ }^{21}$ Zepada v. Zepada, 41 I11. App 2d 240, 190 N.E.2d 849 (1963). Cfr. E. COLLINS, “An Overview and Analisys...", p. 677/711. Sobre as decisões norte-americanas, Kristen CAREY, "Wrongful Life...", p. 2/4.

22 Tristram H. ENGELHARDT, The Foundations of Bioethics, p. 258

23 Sobre a configuração destes processos e dos danos a indemnizar/compensar no sistema norte-americano, Jean-Yves GOFFI, “La Notion de Vie Préjudiciable...", p. 77/86.

${ }^{24}$ Gleitman v. Cosgrove, 1967, 227 a. 2d 689, NJSC. Relatando o caso, Bernard DICKENS, "Wrongful Birth...", p. 85 
era no vizinho estado de New York, onde ela poderia ter abortado aquele feto gravemente mal-formado). O tribunal rejeitou a sua pretensão, com base nos seguintes argumentos: i) a proibição que reinava no estado quanto ao aborto; ii) a impossibilidade de calcular o dano alegado; iii) a contrariedade de tal pedido face à ordem pública. Mas ainda assim uma das opiniões dissidentes deu razão à sua angústia, que obteve também simpatia em largos sectores doutrinais, embora sempre se debatendo com a enorme dificuldade em determinar um quantitativo indemnizatório, porquanto é muito difícil calcular a diferença entre uma existência com o peso de deficiências graves e uma não existência, como ficou assinalado neste caso Gleitman.

A primeira vez que um tribunal superior deu satisfação a um pedido destes foi em 1978 - curiosamente, ou não, pouco tempo depois da legalização do aborto - no caso Becker v. Schwartz ${ }^{25}$, a propósito de um médico que não informou os perigos acrescido de sindroma de Down em gravidezes de mulheres de idade avançada.

Hoje em dia desenha-se uma forte corrente jurisprudencial no sentido de dar satisfação a estes casos, quer os de wrongful conception quer os de wrongful birth.

Diferentemente, a wrongful life continua a ser assaz controvertida, a jurisprudência divide-se e muitos estados já excluíram estas pretensões por via legal.

O primero processo a dar razão a uma wrongful life action foi Curlener v. Bio-Science Laboratories ${ }^{26}$, no qual uma criança afectada pela doença de Tay-Sachs e os seus pais (estes num processo de wrongful birth) accionaram o laboratório que estes últimos tinham procurado para determinar se eram ou não portadores de Tay-Sachs, tendo o referido laboratório emitido um juízo negativo. O Supreme Court da Califórnia começou por distinguir este caso dos precedentes e afastou a sua rejeição com base na suposta dificuldade no cálculo do dano. Desconsiderou igualmente certas concepções morais sobre a vida que continuavam a dominar a apreciação jurídica destas questões. Segundo o Tribunal, pouco releva o facto de que a criança não houvera nascido sem a negligência dos arguidos. Mas já releva a circunstância de ela ter efectivamente nascido, e é no cenário concretamente existente que se deve avaliar se tem direito a ser ressarcida dos danos que sofre.

25 Becker v. Schwartz, 46 N.Y.2d 401, 413 N.Y.S.2d 895, 386 N.E.2d 807 (1978).

26 Curlener v. Bio-Science Laboratories (1980) 106 Cal.App.3d 811, 165 Cal.Rptr. 477. Porém, subsequentemente o estado da Califórnia promulgou leis destinadas a afastar esta pretensão. 


\subsection{A jurisprudência europeia}

Na Europa as acções por wrongful conception têm obtido algum sucesso ${ }^{27}$. Logo em 1980 o Supremo Tribunal Federal (Bundesgerichtshof) condenou um médico por uma esterilização mal sucedida. Na vizinha Espanha, por exemplo, têm-se ressarcido os danos derivados de esterilizações falhadas (por exemplo, repetições do processo de esterilização), mas não já os relacionados com o sustento da criança.

Em contrapartida, as acções de wrongful birth e wrongful life suscitam bem mais controvérsia.

A jurisprudência alemã desce cedo nos oferece decisões que atribuíram ao nascituro o direito à reparação dos danos sofridos pela mãe durante a gravidez, ainda que reconhecendo simultaneamente a ausência da sua capacidade jurídica ${ }^{28}$.

Mais uma vez a Alemanha nos oferece interessantes exemplos. Em 1978 o Tribunal de Apelação de Bamberg proferiu uma decisão referente a um caso que viria a fazer escola ${ }^{29}$, ao negar a atribuição de indemnização a uma mulher que engravidara de gémeos não obstante ter sido submetida a uma esterilização, que se veio a concluir ter sido mal realizada. Em contrapartida, o Supremo Tribunal Federal entendeu o contrário, e conferiu-lhe uma indemnização por danos corporais, bem como alimentos às crianças também a título de indemnização ${ }^{30}$.

Em 1982, o Tribunal de Apelação de Munique negou provimento ao pedido de indemnização por negligência médica apresentado pelos pais e pelo filho que nascera com severas malformações em virtude de não ter sido diagnosticada à mãe uma rubéola que a atacou durante a gravidez ${ }^{31}$, mas esta decisão veio a ser parcialmente rebatida pelo Bundesgerichtshof, que reconheceu a existência de uma pretensão contratual dos pais ${ }^{32}$, decisão esta que foi depois repetida em múltiplos casos posteriores.

27 Marta Nunes VICENTE, “Algumas Reflexões...", p. 124.

28 Decisão do Tribunal Federal de 20 de Dezembro de 1952, que se fundo no âmbito de aplicação diferenciado do parág. 823 do B.G.V., pois enquanto o n. ${ }^{\circ} 1$ se referiria a direitos subjectivos que pressupõem uma pessoa jurídica, já o n. ${ }^{\circ} 2$ abdicaria desse requisito. Decisão comentada por João Álvaro DIAS (“Procriação Medicamente Assistida...”, p. 153) que, porém, faz notar que nem sempre esse tribunal seguiu a referida orientação.

29 OLG Bamberg, 6 de Fevereiro de 1978, JZ 1978, 529, 532.

30 BGH, 18 de Março de 1980, NJW 1980, 1452-1456. Cfr. António Meneses CORDEIRO, Tratado de Direito Civil Português..., p. 324 ss.

31 Olg München, 27 de Fevereiro de 1981, z 1981, 586-589.

32 BGH, 18 de Janeiro de 1983, BGHZ 86, 1983, 240- 255. 
Na decisão relativa ao aborto, de 28 de Maio de $1993^{33}$, o Tribunal Constitucional alemão (BVerfGE) proferiu, ainda que em obiter dictum, uma opinião que veio reverter esta tendência, ao afirmar que em virtude da dignidade reconhecida pela Lei Constitucional alemã a todas as pessoas, jamais a existência, fosse ela de que modo fosse, se poderia considerar um dano ${ }^{34}$. Todavia, os tribunais judiciais, especialmente o Bundesgerichtshof, mantiveram a sua jurisprudência por entender que esta afirmação do $B \operatorname{Verf} G E$ valia apenas para a específica questão da constitucionalidade do modelo de aconselhamento legalmente consagrado para o aborto. O próprio BVerfGe chegou a aderir a esta posição numa das suas secções (I Senat), ao atribuir uma indemnização à mulher que engravidara no seguimento da uma esterilização falhada ${ }^{35}$.

Em França esta questão é invariavelmente marcada pelo caso Perruche ${ }^{36}$, um dos mais famosos de sempre da jurisprudência francesa. Nicolas Perruche nasceu com fortes deficiências (síndroma de Gregg: lesões auditivas e visuais, cardiopatias e neuropatias), em consequência da rubéola contraída pela mãe durante a gravidez (sendo que a mulher chegou a informar os médicos da história clínica da sua família que poderia colocar em risco a criança, e avisou que caso existisse a possibilidade de esta nascer com problemas preferiria abortar) mas que não foi detectada, pelo que os pais accionaram o médico e o laboratório. Depois de em primeira instância ter sido atribuída uma indemnização aos pais, mas não ao filho ${ }^{37}$, o Tribunal de Cassação conferiu aos pais uma indemnização pelo facto de terem sido privados da possibilidade de escolher entre abortar e prosseguir com a gravidez (autodeterminação

33 BVerf, 28 de Maio de 1993, BVerfGe 88, 1993.

34 António Meneses CORDEIRO, Tratado de Direito Civil Português...., p. 325 ss.; David MERCER, "The Wrongful Life Concept...".

35 BVerfGE, decisão de 12 de Novembro de 1997. Cfr. DOSSIER DE L'INSTITUT EUROPÉEN DE BIOÉTIQUE, "La Naissance Handicapée: Un Préjudice Indemnisable?" ; Paulo Mota PINTO, "Indemnização...", p. 9.

36 Cour de Cassation, decisão de 17 de Novembro de 2000. Cfr. Jean-François ABEILLE, "Responsabilité Médicale", p. 129/132; António Pinto MONTEIRO, "STJ, Acórdão de 19 de Junho de $2001 \ldots$..., p. 379 ss.; Anne-Claire MULLER, "L’Affaire Perruche...”, p. 12 ss.; Marta Nunes VICENTE, "Algumas Reflexões...”, p. 118 ss.

Mas já anteriormente os tribunais franceses se tinham defrontado com questões semelhantes (Paulo Mota PINTO, "Indemnização...", p. 8, 9): nascimento no seguimento de um aborto falhado (Cour de Cassation, 2 de Julho de 1982), nascimento de uma criança deficiente porque a mãe não foi vacinada contra a rubéola (Cour de Cassation, 16 de Julho de 1991); erro de diagnóstico de uma doença neurológica hereditária (Cour de Cassation, 26 de Março de 1996).

37 A Cour d'Appel d' Orléans afirmou, na sua decisão de 5 de Fevereiro de 1999, que "sa naissance ou la suppression de sa vie, ne peut pas être considérée comme une chance ou une malchance dont il peut tirer dês conséquences juridiques". 
reprodutiva $)^{38}$, mas também à criança, em virtude dos danos por ela sofridos (que, sublinhe-se, foram provocados pela rubéola e não pelos médicos) ${ }^{39}$.

Esta tendência forçou o legislador a intervir e assim nasceu a lei n. ${ }^{\circ} 2002$ 303, de 4 de Março de 2002 (relativa aos direitos dos doentes e à qualidade do sistema de saúde, também conhecida como Loi Kouchner ou Loi Anti-Peruche), que limita a responsabilidade médica nestes casos, estipulando no seu art. $1 .^{\circ}$ que "nul ne peut se prévaloir d'un préjudice du seul fait de sa naissance", ou seja, o nascimento não pode ser entendido como um prejuízo para ninguém. Esta lei apenas admite a reparação de danos resultantes directamente (em termos de nexo de causalidade) de actos médicos, isto é, quando o acto médico em si mesmo causou a lesão ou a agravou (como sucede por vezes com o trabalho de parto), ou não permitiu a tomada das medidas adequadas para a evitar. Por outro lado, apenas considera os prejuízos sofridos pelos pais, e com isto remete por inteiro a abordagem da questão para os cânones clássicos da responsabilidade civil (arts. 1382. ${ }^{\circ}$ e 1383 do Code Civil francês). Finalmente, admite que os pais possam pedir uma compensação pelos danos sofridos em virtude do nascimento de uma criança cuja deficiência não foi detectada durante a gravidez, mas exclui do montante os encargos especiais que venham a suportar com o filho, isto é, os danos patrimoniais, os quais ficam a cargo da Solidariedade Nacional. Esta norma foi revogada pela Lei n. ${ }^{\circ}$ 2005-102, de 11 de Fevereiro de 2005, que, porém, introduziu no Código de Acção Social francês um art. L. 114-5, sensivelmente com o mesmo teor ${ }^{40}$.

O Reino Unido tem-se mostrado avesso a este tipo de reivindicações ${ }^{41}$. Num caso ainda decidido à luz do common law ${ }^{42}$ recusou uma pretensão por

38 O que já havia sido afirmado pela Cour d'Appel d' Orléans: "[D]ès lors que les fautes commises par le médecin et le laboratoire dans l'exécution des contrats formés avec Mme X... avaient empêché celle-ci d'exercer son choix d'interrompre sa grossesse afin d'éviter la naissance d'un enfant atteint d'un handicap, ce dernier peut demander la réparation du préjudice résultant de ce handicap et causé par les fautes retenues".

39 Bernard MATHIEU, "Constitution et Génome Humain", Annuaire International de Justice Constitutionnelle, v.14, 1998, p. 529

40 "Nul ne peut se prévaloir d'un préjudice du seul fait de sa naissance.

La personne née avec un handicap dû à une faute médicale peut obtenir la réparation de son préjudice lorsque l'acte fautif a provoqué directement le handicap ou l'a aggravé, ou n'a pas permis de prendre les mesures susceptibles de l'atténuer.

Lorsque la responsabilité d'un professionnel ou d'un établissement de santé est engagée visà-vis des parents d'un enfant né avec un handicap non décelé pendant la grossesse à la suite d'une faute caractérisée, les parents peuvent demander une indemnité au titre de leur seul préjudice. Ce préjudice ne saurait inclure les charges particulières découlant, tout au long de la vie de l'enfant, de ce handicap. La compensation de ce dernier relève de la solidarité nationale".

${ }^{41}$ Paulo Mota PINTO, “Indemnização...", p. 10, 11.

${ }^{42}$ McKay v. Essex Area Health Authority [1982], Q.B. 1166. 
wrongful life por contrária à ordem pública. O Congenital Disabilities (Civil Liability) Act 1976 excluiu expressamente pretensões de wrongful life, e no caso McFarlane ${ }^{43}$ as indemnizações por wrongful conception foram igualmente limitadas por se entender que o nascimento de uma criança saudável não poderia ser considerado um dano (embora a mãe tenha sido indemnizada pela perda de rendimentos e outros custos associados ao parto), só sendo indemnizáveis as despesas adicionais de um filho deficiente nos casos de wrongful birth.

$\mathrm{Na}$ vizinha Espanha temos também algumas decisões judiciais sobre o tema: um caso de wrongful birth resultante de um erro na amniocentese ${ }^{44}$, um de falta de informação sobre os riscos de determinada gravidez ${ }^{45}$, entre outros.

Em Portugal contamos até ao momento apenas com uma decisão do Supremo Tribunal de Justiça $(\mathrm{STJ})^{46}$, que não se afastou muito das directrizes da jurisprudência europeia. Em causa estava um pedido de indemnização intentado pelos pais em representação de uma criança (wrongful life action) que nascera com graves anomalias sem que o médico e a clínica de radiologia se tivessem dado conta do facto durante a gravidez e, consequentemente, não informaram os pais, que poderiam ter optado pelo aborto. Entendeu o tribunal que o pedido deveria ter sido formulado pelos pais directamente e não agindo em nome do filho, pois a existir violação seria na esfera jurídica destes, em virtude do deficiente cumprimento do contrato de prestação de serviços médicos, pelo que se verificava uma desconformidade entre o pedido e a causa do pedir. No que respeita à criança ter-se-ia que discutir o direito à não existência, legalmente desconhecido na ordem jurídica portuguesa. Mas ainda que fosse reconhecido, tal direito teria que ser reivindicado pela própria criança quando maior de idade e não pelos pais em seu nome, pois o poder paternal não lhes concede essa legitimidade. Por conseguinte, rejeitou qualquer ressarcimento, quer por danos patrimoniais quer por danos morais ${ }^{47}$.

43 McFarlane and Another v. Tayside Health Board [1999], 4 Sll. E.R. 961.

44 Tribunal Supremo, decisão de 6 de Junho de 1997, resolução n. ${ }^{\circ}$ 495/97.

45 Audiência Provincial de Valência, decisão de 28 de Maio de 2003.

46 Acordão do STJ de 19 de Junho de 2001, processo 1008/01.

47 Comentando esta decisão, António Meneses CORDEIRO, Tratado de Direito Civil Português..., p. 329, 330 (o autor apenas admite uma indemnização aos pais, por violação do contrato de tratamento médico e do dever de informar por parte do médico, mas não uma indemnização ao filho, pois considera incongruente que alguém possa responsabilizar outrem - o médico - por estar vivo); António Pinto MONTEIRO, "STJ, Acórdão de 19 de Junho de $2001 \ldots$.., p. 371 ss.; "Portuguese Case Note", p. 220 ss. (uma nota importante sublinhada pelo autor é a incongruência entre uma decisão que nega, e bem em seu entender, o dano da não-existência mesmo para aqueles que nascem com severas anomalias [pelo menos quando a acção seja intentada pelos pais e não directamente pelos filhos] e um ordenamento jurídico que permite que nestes casos os pais procedam ao chamado aborto eugénico); André 


\section{Direito a nascer são e direito a não nascer}

O direito a nascer saudável ${ }^{48}$ apenas pode ser compreendido no sentido de protecção do embrião face a outras doenças que não aquelas que lhe cabem por força da "lotaria natural" ${ }^{49}$, ou seja, o direito a não padecer de doenças criadas por mecanismos humanos. Mas, mesmo no que respeita àquelas primeiras, pode ainda falar-se no dever dos pais evitarem a transmissão de doenças hereditariamente transmissíveis, cuja efectivação passa em grande parte pelas técnicas reprodutivas.

Desde há muito que este suposto direito se vem discutindo quanto a embriões uterinos, como possível fundamento da imposição de restrições à mulher grávida, nomeadamente a abstenção de comportamentos de risco, tais como a ingestão de álcool ou bebidas alcoólicas, a prática de desportos perigosos (sendo que, pelo menos as duas primeiras hipóteses, têm sentido até antes ou independentemente da gravidez, de modo que a sua imposição pode recair quer sobre as futuras mães quer sobre os futuros pais), e mesmo face a condutas de terceiros lesivas do bem-estar do embrião, tais como transfusões com sangue contaminado com HIV.

Mas é relativamente aos embriões in vitro que a questão se coloca com maior acuidade. É que, em relação a estes, a garantia de um nascimento em boas condições de saúde pode ser feita com maior grau de certeza por força de soluções tais como o DGPI e a selecção de embriões ou a terapia germinal. Pode até pensar-se em levar este raciocínio ao ponto de responsabilizar judicialmente os pais que não tenham recorrido a estes expedientes, uma espécie de negligência parental, quase paralela à negligência médica.

$\mathrm{O}$ direito a não nascer ${ }^{50}$ é dos mais recentes direitos supostamente atribuídos ao embrião, e refere-se a um hipotético direito do embrião uterino a ver interrompida a sua gestação mediante um abortamento (o que faria do

Gonçalves PEREIRA, O Consentimento Informado..., p. 387/391 (em sentido crítico, dado que "acarreta a irresponsabilidade civil dos médicos que se dedicam à medicina pré-natal", embora se mostre renitente na compensação moral da própria criança); Paulo Mota PINTO, "Indemnização...", p. 11 (criticando a decisão do STJ e mostrando-se favorável à wrongful life action); Vanessa Cardoso OLIVEIRA, "Wrongful Life Action...", p. 128 ss.

48 Aceitando este direito, e equiparando-o com o direito a transformar o próprio corpo mediante cirurgia estética, Henri Caillavet, membro do Conselho Nacional de Ética Francês. Diz o autor que 'l'enfant handicapé, parce qu'il naît avec un handicap qu'il n'accepte pas, a la possibilité d'ester en justice contre ses ascendants. (...) Très prochainement, l'enfant obtiendra enfin le droit incontestable à ne pas naître handicapé" (Contribuição de Henri Caillavet ao parecer $n^{\circ} 68$ do Comité Consultatif National d'Éthique (CCNE), "Handicap et préjudice”, 29 de Maio de 2001, at www.ccne-ethique.org/francais/start.htm).

49 Ermelano COSMI, E. MORDINI, “La Bioetica ...”, p. 123.

50 Dando conta deste direito, João LOUREIRO, “Tomemos a Sério...”, p. 29 ss., mas rejeitando-o. 
aborto, não um direito, mas um poder/dever ${ }^{51}$, semelhante ao poder paternal), e paralelamente, um direito do embrião in vitro a não ser transferido para o útero materno quando lhe seja detectada qualquer anomalia ou patologia grave $^{52}$.

Uma vez aceite este direito concomitantemente se aceitará uma acção de indemnização em nome da criança nascida com malformações ou doenças, interposta contra o médico que não detectou essas características, ou contra os pais que, mesmo tendo conhecimento delas, decidiram fazer nascer aquela criança. No fundo, uma indemnização por ter nascido em violação ao seu direito a não nascer, do qual derivaria um direito a ser abortado e um direito a não ser transferido para o útero.

Na verdade, duas questões se confrontam na discussão relativa ao "direito a não nascer":

i) Por um lado, averiguar se este direito não será uma contradição nos termos, o que demonstraria a impossibilidade lógica da sua existência;

ii) Por outro lado, determinar se existirão vidas tão penosas que seria preferível a não-existência. Qual o exacto significado do "direito a não nascer"? Falamos aqui de um direito a não ter direitos? Ou, ao invés, existirá um dever constitucional de viver ${ }^{53}$ ?

\subsection{0 problema da reivindicação de direitos antes do nascimento}

Uma das hipóteses será considerar que a rejeição da personalidade jurídica do embrião e da sua titularidade de direitos impede que lhe seja reconhecido um direito a ser indemnizado por danos que sofreu quando

51 Pois "repugna a aceitação de um dever, ou mesmo tão-só de um ónus, dos pais, no sentido da destruição da vida humana pré-natal" (Paulo Mota PINTO, "Indemnização...", p. 14).

52 Acolhendo claramente esta concepção, a decisão Curlender v. BioScience Laboratories, na qual foi atribuída aos pais e à criança uma indemnização em virtude de não terem sido informados de que eram portadores da doença de Tay-Sachs. Mas o tribunal foi ainda mais longe, ao afirmar inclusive que, caso a informação tivesse sido dada, os pais teriam a obrigação de não fazer nascer aquela criança. Note-se, porém, que nem a jurisprudência Perruche foi tão radical a ponto de reconhecer este direito.

53 A este propósito, mas a respeito de doentes terminais assomados de intenso sofrimento, vide os estudos de José Francisco de Faria COSTA, "O Fim da Vida e o Direito Penal”, p. 759 ss., e "Vida e Morte em Direito Penal...", p. 171 ss.

Refutando a existência de um tal dever, especialmente face ao art. 2. ${ }^{\circ}$ da CEDH, Vera Lúcia RAPOSO, "O Direito à Vida...", p. 83/87. Também negando este dever, mas distinguindo-o da renúncia ao direito de viver, por contrária para à dignidade humana, Manuel Carneiro da FRADA, “A Própria Vida como Dano...”, seguindo a argumentação de J. J. Gomes CANOTILHO, Direito Constitucional e Teoria da Constituição, p. 464; vide ainda Luísa NETO, O Direito Fundamental..., p. 295 ss., 494 ss. 
não era pessoa nem tinha direitos. Mas não tem que ser necessariamente assim. Nem nos parece necessário recorrer à figura dos deveres sem sujeito activo, que, no caso, será um sujeito futuro ${ }^{54}$. Pois é o próprio Código Civil a determinar que a personalidade jurídica se inicia com o nascimento com vida (art. 66.\% CC) e que os direitos dependem dessa personalidade (art. 66.\%/2 CC) mas, ao mesmo tempo, a admitir que alguns dos direitos patrimoniais de que a pessoa virá a ser titular se reportem a um momento prévio ao seu nascimento. Não cremos que surjam nessa altura, pois só podem nascer com a personalidade jurídica. $\mathrm{O}$ que sucede é que retroagem ao passado. $\mathrm{O}$ mesmo poderá suceder com este particular direito patrimonial, que não é, de resto, inédito, pois já na decisão de 30 de Março de 2000 o Tribunal da Relação do Porto havia admitido uma indemnização ao nascituro devido à morte do pai em acidente de viação.

Outra abordagem possível, e de sentido totalmente oposto, parte do pressuposto que só faz sentido reclamar este direito antes do nascimento, momento onde, precisamente, não existe qualquer direito dada a ausência de personalidade jurídica. Nem se diga que ainda faz sentido reivindicar o direito após o nascimento, arguindo a sua violação e pedindo a respectiva indemnização. Pois todos os direitos implicam a possibilidade teórica de serem exercidos no seu devido tempo, quando existe efectiva possibilidade de serem cumpridos/respeitados, o que neste caso não se verifica. Nem há analogia possível com outros direitos que o ordenamento civil garante ao nascituro depois do seu nascimento (alguns direitos patrimoniais), na medida em que estes outros podem efectivamente ser exercidos, ao passo que, do suposto direito a não nascer, apenas são possíveis duas consequências: ou bem que o ser não nasce e, por conseguinte, não chega a exercer o direito; ou bem que nasce, e a única hipótese possível é pedir uma compensação pela nascimento indevido. Por exemplo, caso venha a nascer com algum dano em virtude de factos ocorridos antes da sua concepção, mormente manipulações genéticas nos gâmetas, será lícito afirmar que algum direito seu foi violado? Poderá ser pedida qualquer indemnização em seu nome próprio? Segundo esta tese, o que está em causa são os direitos dos titulares dos gâmetas.

Vejamos qual das teses deve merecer o nosso acolhimento.

Em termos de direito civil os concepturos ou nascituros não concebidos não dispõem de qualquer personalidade jurídica. Em contrapartida, aos nascituros ${ }^{55}$

54 Sugerindo esta hipótese, embora reconhecendo que "rompe com os quadros comuns da responsabilidade aquiliana”, Manuel Carneiro da FRADA, "A Própria Vida como Dano...”. Todavia, este "desvio" dos cânones clássicos é cada vez mais comum no ordenamento jurídico, por exemplo, na responsabilidade por danos ambientais, por manipulação genética, etc.

55 Na doutrina civil fala-se em nascituro a propósito de qualquer ser ainda não nascido, esteja ele já concebido ou ainda não, situação esta última em que toma simultaneamente o nome 
o direito civil reconhece, pelo menos, um estatuto jurídico (mas sem a atribuição de direitos) em matéria patrimonial ${ }^{56}$. Cremos que não se trata de uma atribuição de direitos, mas tão-só de pré-destinação de direitos que irão surgir no futuro. Quando muito teríamos uma atribuição futura e condicional de direitos, mas nem isso pensamos que exista aqui, dado que até esta futura aquisição do direito pressupõe a existência presente de uma entidade jurídica capaz de ser titular de direitos, isto é, de uma pessoa. Ainda assim o Código Civil permite que o nascituro seja beneficiário de doações e sucessões (seja a sucessão legitimária, legitima ou testamentária), conforme o disposto nos arts. 952. ${ }^{\circ}$ e 2033.\%1 CC. Estas normas têm precisamente servido para argumentar a favor da "pessoalidade" do embrião, mormente em termos de direito civil. Porém, entendemos que elas servem precisamente para fundamentar a tese contrária. Pois se o embrião não chegar a nascer, tudo se passa como se a disposição testamentária ou a doação fossem inválidas desde o princípio. Os bens não transitarão para os supostos herdeiros deste embrião (os pais, que seriam seguramente herdeiros necessários em primeira linha), mas sim para as pessoas a seguir indicadas pelo de cujus ou pelo doador, desde logo porque estas disposições não têm por objectivo a protecção dos direitos patrimoniais do nascituro, mas sim daquele que pretende transmitir-lhe os bens. Assim, se a criança morrer logo após o nascimento os bens transitarão para os seus herdeiros, ao passo que se não chegar sequer a nascer com vida os bens passarão directamente para os herdeiros do de cujus que se seguem ao nascituro (art. 2133. ${ }^{\circ} \mathrm{CC}$ ).

Não obstante termos reiteradamente defendido a ausência de personalidade jurídica do nascituro, o seu carácter de tertium genus e a ausência de direitos ${ }^{57}$, parece-nos que, a partir do momento em que o ser humano efectivamente nasce, se torna pessoa, e consequentemente adquire direitos, pode reivindicálos, ainda que o facto que lhes dá origem - ou seja, os pressupostos que accionam o direito - se reportem a um momento anterior à aquisição deste. Parece-nos, pois, que a primeira abordagem do problema é a mais correcta. Esta conclusão é para nós evidente quando se reclama uma indemnização por danos à integridade física (direito a nascer são).

de concepturo, mas dele não nos ocuparemos aqui porque na verdade o que nos interessa é o embrião e o concepturo nem embrião é. Mas deixamos assinalados que algumas das posições jurídicas que a seguir se descrevem aproveitam igualmente ao concepturo.

56 Apontando a incongruência entre a atribuição de capacidade sucessória a nascituro e a paralela denegação de direitos, nomeadamente o direito à vida, Antonio TARANTINO, "Dalla Dichiarazione Universale dei Diritti...”, p. 89.

57 Eduardo OSUNA, Vera Lúcia RAPOSO, “Embryo Dignity...”, p. 737 ss.; Vera Lúcia RAPOSO, "In the Borderline...", p. 152, 153. 
Mas é uma conclusão bem mais controvertida face ao dano da vida defeituoso (direito a não nascer), porquanto face a estas levantam-se problemas acrescidos.

Caso se concluísse que as normas que autorizam o aborto por motivos de lesão do feto visam proteger interesses ou direitos do feto (o que não nos parece possível dado que este não é pessoa nem titular de direitos), ou mesmo o valor da vida intra-uterina, seria mais simples reconhecer este direito a não nascer ${ }^{58}$. Mas temos dúvidas de que seja esse o seu intuito.

Além disso, a consagração constitucional do direito à vida não tem como correspondente um direito à não vida, nem sequer a eutanásia (de pessoas adultas e conscientes) assim pode ser entendida. Até porque um tal direito - e o mesmo se aplica ao direito a nascer - peca desde logo pela ausência de titular. É que o direito a não nascer só pode ter lugar, pela ordem lógica das coisas, antes do nascimento, quando ainda não existe pessoa, logo, falta um ente capaz de ser titular de direitos. E quando finalmente esse ser se torna pessoa - com o nascimento - deixa o direito de ter conteúdo, ao contrário do direito a nascer saudável, que mesmo após o nascimento conserva alguma razão de ser. $\mathrm{Na}$ verdade, o nascimento representa precisamente a violação do direito, e deixa de existir qualquer outra possibilidade de ser exercido, apenas a hipótese de uma compensação. Ao invés, o cumprimento deste direito implica a inexistência definitiva do seu titular e, não havendo titular, tão-pouco pode existir direito ${ }^{59}$. O direito a não ter direitos seria uma contradição nos termos. Mais contraditório ainda quando o agente se queira prevalecer do desvalor da sua vida para com isso auferir dinheiro que lhe permita viver essa vida... sem valor ${ }^{60}$.

\subsection{0 problema do valor da vida}

Como harmonizar estas acções com o dogma da santidade da vida? Será o nascimento de uma criança sempre uma bênção? No caso Thake v. Maurice ${ }^{61}$, no Canadá, afirmou-se que: "I do not accept that it is a part of our culture that the birth of a child is always a blessing".

58 Aflorando esta questão, Paulo Mota PINTO, “Indemnização...", p. 14; Marta Nunes VICENTE, “Algumas Reflexões...”, p.131;

59 De modo semelhante a decisão n. ${ }^{\circ}$ 14488, de 29 de Julho de 2004, da Corte de Cassazione italiana.

60 Manuel Carneiro da FRADA (“A Própria Vida como Dano...") refere a inconciliabilidade entre o fundamento da pretensão e o fim do seu reconhecimento: “... quem contesta a (sua) vida (em si mesma) com o fito de obter uma indemnização não invoca para o efeito o padrão da vida humana normal, saudável, de que quereria usufruir. Pelo contrário: compara a sua vida com a não-vida e alega preferir a não-vida. Isso é incongruente e inconciliável com pedir uma indemnização (para continuar a viver)".

61 Caso Thake v. Maurice [1986] Q.B. 644. 
Os (ainda) incipientes reconhecimentos judiciais do "direito a morrer" em casos de eutanásia levaram à aceitação de que poderão existir vidas às quais a morte seja preferível. "Indeed, it is interesting to speculate whether the real future of the wrongful life action may lie in compensating handicapped children, but in compensating adults denied non-existence through death when life-sustaining treatment is administrated over their objections" ${ }^{\prime 2}$. Ou seja, a vida não tem que ser necessariamente uma benesse, e qualquer decisão judicial que admita a eutanásia acaba por dar provimento a esta tese. A vida pode ser um bem mas também pode, em casos excepcionais, ser um dano ${ }^{63}$.

Caso se conclua que uma vida é desvaliosa poderíamos pensar numa espécie de "eutanásia fetal" ${ }^{64}$, na qual a decisão de viver ou morrer seria tomada tendo em conta o interesse específico do embrião (embora não pelo próprio, mas sim pelo seu representante legal). Claro que esta concepção parte da admissibilidade de partida da eutanásia e da possibilidade de cada um dispor da sua própria existência, tese que sufragamos. Porém, vai mais além, e admite a eutanásia decidida por terceiros, como sucede no caso de pessoas em situação de comatose, totalmente em estado vegetativo. No caso, também a decisão não cabe ao próprio embrião, mas a uma terceira pessoa, e aqui já nos suscita mais dúvidas.

\section{Deveres reprodutivos dos pais}

A pretensão contra os pais pode fundar-se em comportamentos de risco adoptados antes ou após a gestação (abuso de certas substâncias) ${ }^{65}$; na recusa de tratamentos médicos indispensáveis; na desconsideração consciente de informações médicas acerca do estado da criança (ainda que nos custe admitir uma obrigação jurídica de abortar); ou ainda porque, dado o seu

62 Cfr. Bernard DICKENS, “Canada...", p. 93.

63 Desenvolvendo esta tese, Seana Valentine SHIFFRIN, "Wrongful Life...", p. 119 ss., especialmente p. 137.

${ }^{64}$ A expressão é de RAMSEY (P. RAMSEY, "Reference Points in Deciding About Abortion", in The Morality of Abortion (J. T. Noonan Ed.), Harvard Univeristy Press, 1970) citado por MASON (Ken MASON, "Abortion and the Law", p. 73, 74), partidário desta tese, com base no argumento de que assim oferece ao feto não viável "a choice as to its mode of death". Anastasios MORAITIS ("When Childbirth Becomes Damage...", p. 54) fala em "pre-natal medically assisted suicide”. Também aproximando esta questão da eutanásia, da renúncia a direitos de personalidade e à capacidade jurídica, Manuel Carneiro da FRADA, "A Própria Vida como Dano...".

65 No caso Stallman v. Youngquist (125 Ill. 2d 267, 531 N.E.2d 355 (1988)) o Supremo Tribunal do Illinois condenou uma mãe por ter causado negligentemente lesões no feto (todavia, não impeditivas do nascimento) ao causar um acidente de automóvel. 
estado de saúde, os pais nem deveriam ter procriado (a questão é particularmente pertinente nos casos de portadores de HIV). Neste último caso o filho reclama pelo facto dos pais não se terem abstido de procriar ou por não terem abortado. Ou seja, se ainda há poucas dezenas de anos o aborto surgiu como um direito reprodutivo agora emerge como um dever.

Até ao momento temos raciocinado no pressuposto de que o aborto é uma possibilidade (eventualmente, pelo menos em casos concretos, será um direito) deixada na escolha dos pais. Mas agora passamos para a sua categorização como um poder/dever e abre-se a porta a que os filhos (e daqui a nada, quem sabe, o próprio Estado) possam responsabilizar os pais por esta sua escolha. Isto mesmo que a criança não sofra de nenhuma doença, mas simplesmente porque preferiria não ter nascido.

O exponencial progresso das técnicas de reprodução assistida e outras técnicas que lhe são complementares (mormente a terapia génica) veio permitir, pelo menos em termos científicos, dar à luz filhos perfeitos ou, pelo menos, mais próximos disso do que quando nasciam somente por desígnios da natureza. Pode-se pois perguntar se a pessoa que nasça com uma doença ou malformação poderá intentar um processo contra os pais, argumentando que estes deveriam ter recorrido à terapia génica ou utilizado gâmetas de dadores para substituir os gâmetas do progenitor que lhe transmitiu a doença. E porque não, indo ainda mais longe, permitir que processe os pais por não ter nascido mais perfeita (o que teria sucedido caso estes tivessem recorrido ao auxílio da ciência), ainda que não se trate verdadeiramente de uma criança doente. Parece que chegou agora o tempo em que as crianças poderão responsabilizar os pais pela recusa de se submeter a testes pré-natais ou pela posterior recusa de interromper a gravidez de acordo com o resultado destes.

Os deveres reprodutivos podem surgir em diversos cenários. Ainda que não seja pensável que os pais tenham originado conscientemente um embrião mal-formado ou portador de doença grave, o certo é que em certas situações é previsível tal resultado (como nos casos em que os pais abusam de álcool ou de estupefacientes ou são portadores de doenças geneticamente transmissíveis). Poderá entender-se que conceber uma criança em tais circunstâncias é um acto danoso, violador da autonomia da criança.

Também as técnicas reprodutivas podem fundamentar um processo judicial deste tipo. As técnicas permitem que os portadores de algumas mutações genéticas possam reproduzir-se com o auxílio da ciência. Porém, os seus filhos serão igualmente portadores da mesma mutação. Por exemplo, a infertilidade de alguns pacientes masculinos resulta de mutações de fibrose cística, que os impede de ejacular. As técnicas reprodutivas permitem-lhe ultrapassar esse obstáculo, mas em $50 \%$ dos casos a criança será portadora dessa mesma mutação. Será esse um preço razoável a pagar? Será licito 
permitir a alguém ter um filho existindo a probabilidade, senão mesmo a certeza, de que esse filho não nascerá saudável? E note-se que estamos aqui a falar de uma anomalia de pouca gravidade, mas poderíamos transpor este mesmo raciocínio para casos mais graves.

Esta consideração conduz à seguinte questão: porque procriamos? As repostas são diversas, variando geográfica e cronologicamente (o desejo de amar e de ser amado, uma forma de manter o nome da família e a riqueza, a necessidade de mão de obra familiar; o desejo de alguém que nos cuide na velhice). Sempre se dirá que a principal causa da reprodução radica num dos mais profundos e fortes desejos humanos: a aspiração de prolongar a nossa existência no mundo após a morte física do corpo. O ponto fulcral é que as crianças não são geradas no seu próprio interesse. Por mais planeadas que tenham sido, elas visam sempre satisfazer o interesse de alguma outra pessoa ${ }^{66}$.

E quanto ao interesse do futuro ser, daquele que se sabe de antemão que nascerá com anomalias graves? Deveremos interromper a sua gestação, seguindo a ideia de que "being dead or being unconceived could be treated as equivalent to permanent unconsciousness"67?

\section{0 dano da vida}

O principal impedimento ao reconhecimento do dano da vida por parte dos tribunais reside na aberração da qualificação da própria vida como um dano, isto é, um facto ilícito. Mas, em bom rigor, a ilicitude reside numa certa forma de vida, e não na vida em si.

Outra dificuldade deste dano prende-se com a sua avaliação. Pois os processos de wrongful life implicam sempre uma comparação (praticamente impossível) entre uma vida e uma não vida, o que parece tornar impraticável identificar o dano que se invoca e calcular a consequente indemnização ${ }^{68}$. Esse dano, caso exista (e como veremos pelo argumento seguinte, é de existência duvidosa) parece não se dever a ninguém, porque nem os médicos nem os pais o provocaram (quando existe um responsável directo pelo dano o caso é distinto). A estes apenas pode ser imputada a decisão de permitir o nascimento de uma criança nestas condições.

66 Cfr. Tristram H. ENGELHARDT, The Foundations of Bioethics, p. 259.

67 Cfr. Jonathan GLOVER, "Future People Disability...", p. 440.

68 Desenvolvendo o raciocínio da não comparação entre a existência e a não existência, Walter GLANNON, “The Morality of Selective Termination”, p. 99; Jean-Yves GOFFI, "La Notion de Vie Préjudiciable...”, p. 81/86; David HEYD, Genetics..., p. 21 ss. 
Diferentemente, nos casos de lesões pré-natais directamente causadas por um terceiro (usualmente um médico, mas podemos igualmente pensar no agressor da mãe) ou mesmo pela própria mãe, a comparação, para efeitos de cálculo da compensação, opera entre a situação na qual a criança acaba por nascer (nascimento com o dano) e aquela que existiria se não fosse a lesão (nascimento sem o dano), pelo que aqui o valor negativo é atribuído à vida defeituosa e o valor positivo à vida saudável, como o demonstra a prática habitual de atribuir indemnizações nos casos em que a vida passa de saudável a não-saudável por força de um acto de terceiro. Em contrapartida, na wrongful life, o valor positivo é atribuído à ausência de vida, como nos diz Goffi ${ }^{69}$. O dano não é anterior ao nascimento, nem resulta do nascimento, é o próprio nascimento, diz o autor.

Note-se, porém, que estamos a partir do pressuposto de que a vida é sempre e necessariamente um valor positivo, o que é altamente duvidoso. $\mathrm{O}$ que vamos agora defender é que, em certas situações de clamorosa deficiência, limitação e dor, a vida surge como um minus e não como um plus e, por conseguinte, o dano deve ser atendível. Não o dano da vida em si mesma, mas o dano das condições dessa vida ${ }^{70}$.

Reconhecemos que a questão é assaz complexa, a começar na delimitação do dano. Será que o dano consiste no mero facto do nascimento? Mas a opção contrária seria, pura e simplesmente, não nascer. Mesmo que a anomalia fosse tratada por terapia génica (quando esta seja um tratamento a ter em consideração) há quem sustente que aquele indivíduo continuaria a não nascer, pois o argumento da "não-identidade" diz-nos que a alteração do genoma implica a alteração do indivíduo em si mesmo, pelo que aquele que nasceria não seria já ele, mas um outro ${ }^{71}$. De modo que se tornaria impossível proceder a uma comparação diferencial entre a sua situação actual (as condições em que nasceu) e a situação em que estaria se algo tivesse sido feito (pois não teria nascido). Mas deixamos já claro que o argumento da não-identidade nos parece difícil de sustentar, sob pena de reduzirmos a pessoa ao seu genoma, de tal forma que qualquer intervenção genética implicaria uma mutação da

69 Jean-Yves GOFFI, “La Notion de Vie Préjudiciable...", p. 81.

70 "[É] crucial distinguir, no âmbito daquilo que se designa genericamente como a "responsabilidade por uma vida deficiente", entre o dano da vida propriamente dita e o dano da "deficiência" que essa mesma vida comporta" (Manuel Carneiro da FRADA, "A Própria Vida como Dano..."), expondo de seguida o autor a diferença entre a alegação da vida como um dano e da deficiência como um dano.

71 Sobre o problema da não-identidade (nonidentity problem), Derek PARFIT, Reasons and Persons, p. 351/379, e também a apreciação de Ruth CHADWICK, Doris SCHROEDER, Applied Ethics..., p. 269 ss.; Pilar OSSORIO, "Inheritable Genetic Modifications”, p. 253 ss. 
pessoa, mesmo em seres adultos, que nesta perspectiva deixariam de ser o que sempre foram para se transformar num ser distinto.

Mesmo abstraindo destes argumentos a questão permanece complexa. Se recordarmos a finalidade da atribuição de indemnização concluiremos que esta visa colocar a pessoa na situação em que estaria caso o dano não tivesse ocorrido. Mas, nestas situações, tal reposição implicaria que a pessoa nunca tivesse nascido, pelo que teríamos que comparar uma existência povoada pela doença com uma não-existência ${ }^{72}$. E se optarmos pela reconstituição natural - a finalidade precípua da responsabilidade civil (art. 566.\%1 CC) - eis que teríamos que matar a criança.

Dadas as dificuldades teóricas e práticas supra expedidas relativas à avaliação deste dano sugere-se que a comparação deva operar, não entre existência e não-existência, mas sim entre a existência de uma pessoa dita "normal" e a existência da pessoa nascida naquelas condições ${ }^{73}$. Partindo do pressuposto que qualquer criança trazida ao mundo deve contar com um mínimo de condições, podemos considerar que se verifica um dano (indemnizável) quando se tenha decidido o seu nascimento mesmo que desprovida desse mínimo ${ }^{74}$, e assim evitamos embaraçosas comparações entre existência e não-existência.

Para além da identificação do dano, complexa é também a sua quantificação. Mas não impossível, dado que os tribunais atribuem sistematicamente indemnizações a danos difíceis de quantificar. Na verdade, assim sucede com qualquer tipo de dano moral, e é pacífico o reconhecimento da sua compensação.

Mas o principal argumento contra o reconhecimento deste dano foi, desde sempre, o sofismável argumento da santidade da vida, no sentido

72 Joel FEINBERG (Harm to Others, p. 99) distingue entre "harming" e "wronging": segundo Feinberg, a criança só foi "wronged" quando a sua condição é tão grave que a não existência seria preferível à existência (uma explicação crítica das teses de Feinberg em Hamish STEWART, "Harms...", p. 49/56).

Esta distinção terminológica não é inédita na doutrina anglo-saxónica (John HARRIS, Clones..., p. 108 ss.) e pode ser expressa nos seguintes termos: "The mother and the doctor may have harmed the child, but if that child has a live worth living, albeit a disabled one, the she has not been wronged by being brought to birth, although she has of course been thereby harmed" (John HARRIS, Clones..., p. 117). Mas esta dicotomia é demasiado confusa para os padrões de responsabilidade civil do modelo jurídico continental. Aliás, mesmo este seu raciocínio acabe por cair no delicado cotejo existência/não existência.

${ }^{73}$ Margaret BRAZIER, Medicine... p. 172 (analisa o custo de criar uma criança nestas condições com o custos de uma criança normal).

74 Joel FEINBERG, Harm to Others, p. 101 e, de certa forma, também Bonnie STEINBOCK, "The Logical Case...", p. 19. 
que qualquer vida, por mais dolorosa e degradante que fosse, seria sempre preferível a uma não-vida.

Para obviar a estes obstáculos, alguns tribunais concederam efectivamente indemnizações, mas não pelo dano a vida, e sim pela dor e sofrimento que a criança padece por viver com a sua anomalia ou doença. Contudo, mesmo estes danos morais são controvertidos. Mais consensual é a atribuição de uma indemnização aos pais pelos custos de um filho tido como "normal" acarreta (note-se que apenas esses, e não os meros custos de educar uma criança, pois supõem-se que esses foram aceites pelos pais ao prosseguir com a gravidez).

Será que estas pessoas (supondo que chegaram efectivamente a nascer) vivem efectivamente vidas que não merecem ser vividas? A vida de uma pessoa doente ou deficiente não merece ser vivida? Pode um sujeito jurídico reclamar compensação pelo seu nascimento, quando, na sua ausência, nunca seria ele sujeito de direitos?

De acordo com os seus detractores, as acções de wrongful life teriam precisamente por consequência uma hierarquização de vidas, cindindo as boas e meritórias das más e penosas, que deveriam ser destruídas. Ora, nunca um tribunal afirmou tal coisa. Sendo a indemnização concedida, ela foi-o com base no dano constituído pela doença ou deficiência, e não pela vida, cuja classificação como dano nunca esteve em causa ${ }^{75}$. O que sucede é que este dano está necessariamente ligado a uma vida e a uma pessoa, e dai a aparente confusão de identidades. O erro consiste aqui em não diferenciar o ente físico "corpo" com a pessoa jurídica que o titula. Não são a mesma coisa, muito embora só tenha sentido falar em "corpo" e em "doença” caso tenha existido um nascimento que, por sua vez, tenha dado lugar a uma pessoa jurídica.

A recusa de uma compensação padece do mesmo tom paternalista, e quase masoquista, que encontramos em muitas outras decisões judiciais (o caso Pretty $^{76}$ é paradigmático), onde a dignidade humana surge umbilicalmente ligada à ideia de comunidade, e para as quais o que interessa (à comunidade, que não ao próprio) é estar vivo, independentemente das condições de existência.

\section{A responsabilidade do profissional de saúde}

Avançando agora no nosso raciocínio, cabe decidir quem deve arcar com o "prejuízo". Que dizer das decisões que negam a responsabilidade médica nestes casos? Se é certo que não podemos imputar as fatalidades aos outros,

75 Uma das polémicas associadas a este tipo de acções envolve a discriminação e o juízo negativo que supostamente se faz aos doentes e aos incapacitados. Ora, não é esse o objectivo, mas sim a doença ou a incapacidade, que ninguém discute ser um mal que deverá evitar-se.

76 Pretty v. Reino Unido, n. ${ }^{\circ}$ 2346/02, decisão de 29 de Abril de 2002, TEDH. 
na tentativa de obter algum ressarcimento pelos desaires do destino, também é verdade que certas ocorrências, ainda que não devidas a ninguém, bem poderiam ter sido evitadas, e que existem pessoas cuja função é precisamente evitar, ou pelo menos informar, da sua verificação. Quando assim não suceda verifica-se um caso de responsabilidade negligente que, ao fim ao cabo, pouco difere das responsabilidades que recaem sobre outros profissionais. Se resumirmos este enredo à sua versão mais básica, a verdade que permanece é a seguinte: por força de uma conduta (acção ou omissão), alguém (um médico) causou danos a outrem (o ser que nasceu), de modo que agora terá de o ressarcir ${ }^{77}$.

\subsection{Falta médica e nexo de causalidade}

A responsabilidade civil assenta na existência de um nexo de causalidade entre uma determinada conduta e um determinado dano. No caso, trata-se de verificar se a falta cometida pelo médico, no incumprimento da obrigação contratual de informar o paciente (a qual pode resultar ou da ausência de comunicação do resultado de um exame, ou da total omissão da realização do exame, o que configura já um erro de diagnóstico), é causa da deficiência ou doença da criança, de forma a concluir-se pela sua responsabilidade médica. Esta conexão é avaliada à luz da teoria da causalidade adequada, consagrada no art. 563. ${ }^{\circ}$ do nosso CC ("A obrigação de indemnização só existe em relação aos danos que o lesado provavelmente não teria sofrido se não fosse a lesão") ${ }^{78}$.

E eis aqui o problema: será que existe vínculo de causalidade adequada, uma vez que não foi a conduta do médico a provocar directamente tais lesões na criança ${ }^{79}$ ?

77 Sublinhando o papel da responsabilidade civil do médico como forma de fomentar a diligência, Fernando ARAÚJO, A Procriação Assistida..., p. 100, André Gonçalves PEREIRA, O Consentimento Informado..., p. 391. Em contra, no sentido de que a responsabilidade civil, tal como está configurada entre nós, não pretende impor "uma reacção incondicional ou indiscriminada" àqueles que supostamente tenham causados danos, mas actuar apenas desde que verificados certos pressuposto (dano, ilicitude, culpa e nexo causal), Manuel Carneiro da FRADA, "A Própria Vida como Dano...".

Afastando aqui uma prática negligente do médico e centrando a indemnização na falta da informação adequada, Bonnie STEINBOCK, “The Logical Case...”, p. 15/20.

78 Fernando Pires de LIMA; João de Matos Antunes VARElA (Código Civil Anotado, Vol. I, p. 578) apelam à definição de Vaz Serra: "determinada acção ou omissão será causa de certo prejuízo se, tomadas em conta todas as circunstâncias conhecidas do agente e as mais que um homem normal poderia conhecer, essa acção ou omissão se mostrava, à face da experiência comum, como adequada à produção do referido prejuízo, havendo fortes probabilidades de o originar".

79 "A responsabilidade do médico que violou o seu dever de informação quanto a essa deficiência não pode, por princípio, ser equiparada à responsabilidade do "real" causador da vida deficiente. A responsabilidade deve atingir aquele a quem se tem de atribuir a causa essencial 
Na sua decisão de 14 de Fevereiro de 1997, no caso “Quarez”, o Conseil d'État deparou-se com uma falha na realização da amniocentese numa gravidez tardia que não permitiu detectar que a criança padecia de trissomia 21, não obstante ter sido feita a pedido da mãe com a expressa salvaguarda de que abortaria em caso de resultado positivo. Atribuiu aos pais uma indemnização por danos morais e patrimoniais, mas negou-a à criança, com base na ausência de nexo de causalidade entre a sua doença e qualquer acto médico (isto é, a trissomia existia antes e independentemente da amniocentese).

Porém, também é certo que em muitas destas situações o que em regra se verifica são erros derivados de exames laboratoriais. Ora, este é precisamente um dos casos em que a actividade médica, que em regra se resume a uma obrigação de meios, se transmuta numa obrigação de resultado, pois atendendo ao elevado grau de especialização alcançado pelos exames laboratoriais, em que a margem de incerteza é praticamente nula, sobre aquele que analisa os resultados destes exames recai também uma obrigação de resultado. Logo, se o médico analista "fornece ao cliente um resultado cientificamente errado, então, temos de concluir que actuou culposamente, porquanto o resultado transmitido apenas se deve a erros de análise" (Acórdão do STJ de 4 de Março de 2008) ${ }^{80}$.

De modo que a situação se distancia dos casos em que a mãe sofre lesões físicas durante a gravidez, ou inclusive antes da concepção, mas que depois se repercutem no seu filho, tais como acidentes de viação ou transfusões com sangue contaminado ${ }^{81}$.

A solução será mais simples em ordenamentos, como o francês, onde, ao invés da causalidade adequada, se opera predominantemente com a teoria da equivalência das condições, que toma como causa de um evento todo o facto sem o qual este não se teria produzido, o que alarga substancialmente

do surgimento do "alegado" prejuízo. Quem apenas não afastou um perigo que ele próprio não ocasionou não lhe pode ser equiparado" (Manuel Carneiro da FRADA, "A Própria Vida como Dano...").

80 Ressalvamos, porém, a hipótese da falibilidade do próprio exame, cuja percentagem de exactidão é de cerca de 90 a 95\%. Cfr. Rute Teixeira PEDRO, A Responsabilidade Civil do Médico, p. $98 / 102$.

81 Veja-se, por exemplo, a decisão do Supremo Tribunal Federal alemão (BGHZ 8, 243) que concedeu uma indemnização à criança que nasceu com sífilis em virtude de uma dessas transfusões efectuadas à sua mãe dois anos antes da sua concepção.

Questão diferente é a indemnização por danos morais ao nascituro cujo pai foi morto durante a sua gestão e que ele não chegou a conhecer. A jurisprudência portuguesa apresenta decisões díspares a este respeito: umas vezes concedendo a indemnização (Acórdão da Relação de Lisboa de 28 de Janeiro de 1977); outras vezes negando-a (Acórdão da Relação do Porto de 13 de Abril de 1989). 
o leque de causas juridicamente atendíveis e abarca facilmente a conduta do médico ${ }^{82}$.

Nos casos em análise a falta médica reside na omissão de todos os conhecimentos, diligências e cuidados para dar a conhecer aos pais a condição do filho, seja porque não realizaram os exames devidos, seja porque os interpretaram mal, seja porque não comunicaram aos pais o resultado. Isto é, o médico incumpre os seus deveres de informação em desrespeito pelas leges artis, e com isto acaba por causar um dano, nos mesmos termos em que um médico será responsabilizado caso realize uma intervenção cirúrgica sem dar ao paciente as informações pertinentes, ainda que dela não advenha qualquer dano. Se neste último caso a falta de informação - ponto nevrálgico do consentimento esclarecido - esvazia o consentimento do paciente, também no caso sub judice se pode dizer que o consentimento dos pais para prosseguir a gravidez não era um consentimento esclarecido, na posse de todas as informações relevantes.

Esta conclusão não é infirmada pelo facto de a condição do nascituro ser incurável, pelo que a comunicação da informação não conduziria à sua cura, mas sim à sua não-existência. É que a partir do momento em que a lei admite a interrupção da gravidez de um feto com anomalias graves está com isto a admitir que uma vida nestas condições pressupõe, efectivamente, um dano, o qual não reside na vida em si, e muito menos na pessoa que a vive, mas sim nas anomalias com que é forçado a viver (ainda que se entenda, como nos parece, que a sua finalidade não é a protecção do feto ou da pessoa assim nascida).

De modo que, embora a doença ou malformação não tenham sido causadas por um médico, certo é que a sua actividade, quando desenvolvida segundo as leges artis, poderia ter evitado o nascimento com aquele dano e isto, segundo cremos, já funciona como nexo de causalidade suficiente ${ }^{83}$. Pois uma vez concluída que determinada vida representa um dano para a pessoa, e sendo o médico o responsável pelo facto de a pessoa viver essa vida, existe um nexo de causalidade, ainda que indirecto ${ }^{84}$, entre este e o dano, mesmo que outros factores tenham para ele concorrido.

82 Virginie BONNINGUE, Naissance..., p. 27, 28, 84/86 ; DOSSIER DE L'INSTITUT EUROPÉEN DE BIOÉTIQUE, "La Naissance Handicapée : Un Préjudice Indemnizable?", p. 4/6.

83 Pierre Sargos (citado por Anne-Claire MULLER, "L'Affaire Perruche...", p. 18), conselheiro da Cour de Cassation, diz que a responsabilização do médico só é incompreensível para quem se apegue a um nexo de causalidade biológico.

Sobre a configuração da causalidade neste caso concreto, DOSSIER DE L'INSTITUT EUROPÉEN DE BIOÉTIQUE, “La Naissance Handicapée : Un Préjudice Indemnizable?”, p. 6/8.

84 Mas também este nexo de causalidade encontra acolhimento no nosso art. $563 .^{\circ}$ do CC, segundo Fernando Pires de LIMA; João de Matos Antunes VARELA, Código Civil Anotado, Vol. I, p. 579. 
E nem que diga que assim estamos a considerar o nascimento de uma pessoa como um dano em si mesmo. Pois se a deficiência que a criança transporta tivesse sido directamente causada por um acto médico ninguém hesitaria em atribuir-lhe uma indemnização ou arguiria que estaríamos a desvalorizar a sua vida.

A partir do momento em que a lei admite o aborto em caso de deficiência grave do feto mal se compreenderia que os pais se vissem privados dessa escolha (que, afinal, não pode caber a outrem senão aos pais ${ }^{85}$, já que o feto não pode decidir por si) por força de um erro médico. Note-se que o dano não é a criança em si mesma, mas a ausência da possibilidade de escolha. Se admitirmos que o aborto, nas condições legalmente explicitadas, é um direito (e o art. 142. \%/1/e CP confirma esta visão das coisas), então, a decisão pelo não exercício é, ainda, exercício de um direito.

Simplesmente, se concebermos a questão nestes termos, o que teremos é um caso de wrongful birth (dano para os pais) e não de wrongful life. Como podemos nós responsabilizar o médico perante o filho por omissão de um dever de informação que não foi estabelecido no interesse do filho? Ou será que teremos que considerar que o aborto, quando realizado nestes casos, opera no sentido do melhor interesse daquele? Outra hipótese será considerar que os deveres de informação do médico também relevam face ao filho não nascido à luz dos contratos a favor de terceiros, no âmbito do qual o contrato de prestação de serviços médicos implicaria deveres colaterais de protecção face ao nascituro. Será que os deveres médicos existem apenas em face da paciente-mãe, ou igualmente do paciente-nascituro? Paulo Mota Pinto ${ }^{86}$ admite que o nascituro seja incluído pelos pais no âmbito de protecção do contrato de tratamento ou que tenhamos aqui um contrato com eficácia de protecção para terceiros. Marta Nunes Vicente ${ }^{87}$ apela também à figura do contrato a favor de terceiros, e defende que o contrato de prestação de serviços médicos implica deveres colaterais de protecção face ao nascituro. De modo que o seu direito à indemnização derivaria, não da violação de um dever de informação, mas sim destes deveres de protecção, e seria entre a violação de tais deveres e o dano sofrido que se deveria aquilatar do nexo de causalidade ${ }^{88}$.

85 Em bom rigor, se fundarmos a indemnização concedida aos pais na privação do direito de escolher em abortar ou não, teríamos que concluir que tal indemnização caberia apenas à mãe, pois esta opção depende inteiramente dela, não podendo o pai forçá-la a prosseguir a gestação de um feto com graves anomalias ou impedi-la de o fazer caso essa seja a sua vontade. Sobre isto vide o nosso "O Dilema do Rei Salomão...".

86 Paulo Mota PINTO, “Indemnização...”, p. 16.

87 Marta Nunes VICENTE, “Algumas Reflexões...”, p.129/132.

88 Uma outra explicação possível é a de Luc MAYAUX ("Naissance d'un Enfant Handicapé: La Cour de Cassation au Péril de la Causalité", Révue Général du Droit des Assurances, n. ${ }^{\circ} 1$, 


\section{As wrong actions à luz do ordenamento jurídico português}

Não temos a menor dúvida quanto ao ressarcimento dos pais em qualquer das situações:

i) Na wrongful birth action por danos morais e patrimoniais. Não todos os custos derivados da educação e sustento de uma criança, mas tão-só os relacionados com a deficiência da criança, pois os pais aceitaram voluntariamente aquela gravidez, logo, "conformara-se" com as despesas do primeiro tipo, que derivam da lei (art. 1878.\% CC) por força do poder paternal ${ }^{89}$;

ii) Na wrongful conception action por danos meramente patrimoniais. Temos dúvidas que possa existir compensação por danos morais neste último caso, dado que o nascimento de uma criança sã (se assim não for será uma acção do primeiro tipo) não pode em regra ser visto como um dano moral, embora seja certo que se verifica aqui uma violação do direito à não reprodução.

Segundo Paulo Mota Pinto ${ }^{90}$, o nascimento de uma criança saudável não pode dar causa a uma indemnização por danos morais, tanto mais que o nosso sistema jurídico apenas autoriza o aborto em condições delimitadas, pelo que o "dano não patrimonial da falta de autodeterminação na paternidade ou maternidade não pode, depois da concepção, relevar autonomamente, pois tal seria contraditório com a proibição (e punição) do aborto". Sucede, porém, que a lei n. ${ }^{\circ}$ 16/2007, de 17 de Abril, veio consagrar (contra aquilo que defendemos) o aborto como um direito, que pode ser exercido sem justificação no período inicial da gestação. No presente condicionalismo, que o autor não teve oportunidade de ter em conta, esta argumentação já não singra. Existe de facto aqui a violação do direito à não reprodução $0^{91}$. Ainda assim, cremos

2001, apud Marta Nunes VICENTE, “Algumas Reflexões...”, p. 127), segundo a qual o dano só surge com o nascimento, dado que in utero não existe ainda dano, pelo que se pode considerar que o nascimento é causa do dano e o médico, por sua vez, é causa do nascimento. Uma exposição de outras soluções para afirmar o nexo de causalidade em Marta Nunes VICENTE, “Algumas Reflexões...", p.127/129.

89 Também assim Marta Nunes VICENTE, “Algumas Reflexões...”, p. 121.

90 Paulo Mota PINTO, “Indemnização...”, p. 22, 23.

91 Aquilo que Paulo Mota PINTO (“Indemnização...", p. 13, 16) designa "dano do planeamento familiar", e mesmo de "liberdade reprodutiva negativa" (p. 16). Ficámos na dúvida sobre a posição do autor quanto a uma eventual violação deste direito por parte do médico que não informou os pais, pois a certa altura diz-nos que a responsabilização dos médicos não resulta da violação da alínea c) do art. 142.\%1 do Código Penal (p. 14), para depois afirmar que a ilicitude possa resultar da violação deste direito (p. 16). Ora, se admitirmos que esta norma visa proteger o direito à não reprodução, cremos que é a violação desse direito, que o 
que não é susceptível de indemnização por danos morais, dada a "contradição normativa inultrapassável com os valores subjacentes às normas que protegem o direito à vida e o bem jurídico "vida em formação", fazendo funcionar o autor o art. 496.\%1 CC, ou seja, concluindo que este dano é um daqueles que não merece a tutela do direito. Excepto, como Mota Pinto ressalva, no caso de danos que resultem do particular sofrimento da gravidez, ou outros danos morais especiais, que vão para além do mero nascimento de uma criança, concepção esta que tem sido seguida mesmo pelos tribunais que rejeitam acções de wrongful conception (por exemplo, Cour de Cassation, decisão de 25 de Junho de 1991).

No que respeita à wrongful life defrontamo-nos com um problema: é que o juízo acerca da "danosidade" (o peso) da vida é feito por outrem que não o próprio. Em regra falamos de pessoas com um tal grau de deficiência que jamais estarão em condições de fazer o pedido em nome próprio, ou sequer de nele serem ouvidas, sendo os pais ou outro representante legal que actuam em seu nome e aquilatam da gravidade dos mesmos danos. Não é, certamente, inédito. O ordenamento jurídico é prolífero em acções intentadas por pais, curadores ou tutores, em nome de menor ou incapaz, pedindo uma indemnização ou compensação por danos que os próprios não estão em condições de avaliar. Mas trata-se então de danos de outra espécie, mais facilmente perceptíveis. Aqui a especificidade do dano - saber se a vida naquelas condições é preferível à não vida - exige que seja o próprio a fazer essa avaliação. Idealmente, os processos de wrongful life apenas deveriam ser

próprio autor reconhece, que funda a pretensão dos pais face ao médico (mais propriamente, a pretensão da mãe).

Mota Pinto condiciona a atribuição da indemnização ao carácter não ilícito do aborto caso o médico tivesse cumprido os deveres contratuais de informação e este pudesse ter sido levado a cabo (p. 13). Note-se, todavia, que o autor raciocina no quadro do regime vigente antes da alteração de 2007. Sucede que após esta alteração legal tal limitação poderá ter-se tornado inútil, na medida em que hoje, dentro do prazo de 10 semanas, é possível interromper a gravidez ainda que o feto seja são. Como bem realça o autor, "quanto mais restritivo for o regime da ilicitude da interrupção menor "espaço" haverá para exercer acções de wrongful birth ou de wrongful life" (p. 14).

$\mathrm{E}$, acentuam os tribunais alemães e austríacos, desde que o objectivo dos pais ao recorrer àquela solução anti-concepcional fosse efectivamente evitar a reprodução (Anastasios MORAITIS, "When Childbirth Becomes Damage...", p. 49). No seguimento desta jurisprudência, Marta Nunes VICENTE (“Algumas Reflexões...", p. 124, 125) insere uma limitação ao ressarcimento dos danos patrimoniais ligados ao sustento da criança, condicionando-os à verificação de que o intuito dos pais ao recorrer ao método anti-concepcional era efectivamente evitar descendência e não, por exemplo, salvaguardar a saúde da mãe. Pelas razões expostas não nos parece que a finalidade dos pais deva ser relevada. É que, podendo embora não ser esta a sua intenção primeira, pode suceder que entretanto tenham planeado a vida de acordo com aquela decisão que, supostamente, lhe garantia ausência de descendência. 
admitidos quando a criança tivesse capacidade de fazer um tal juízo, porque se trata de uma apreciação subjectiva ${ }^{92}$. Será que podemos operar aqui com a vontade presumida? A partir de que patamar se torna a vida intolerável? Recordemos que há pessoas atacadas por doenças gravíssimas que vivem existências ricas e felizes, e pessoas de boa saúde que vivem totalmente infelizes. Existem existências tão duras que, face a elas, a não-existência seria uma benesse, mas este é um juízo eminentemente pessoal, que carece de ser feito pelo próprio, pois parece-nos que este pode ser um daqueles actos "puramente pessoais" a que se refere o n. ${ }^{\circ} 1$ do art. $1881 .^{\circ}$ do $\mathrm{CC}^{93}$. E corremos certamente o risco de avaliarmos negativamente a vida de alguém que pode até nem se sentir lesado pela forma como vive $\mathrm{e}^{94}$.

Se este arrazoado milita contra a wrongful life, do lado oposto emergem bons argumentos a seu favor.

Pois independentemente do dano que exista para a própria pessoa, uma vida marcada pela deficiência é, objectivamente, uma vida mais limitada do que as restantes. Não se trata de operar aqui com uma presunção de dano, mas de avaliar as condições desta existência face às da maioria ${ }^{95}$. Cremos que ninguém ousará contestar o carácter lesivo da deficiência, pois que se ela ocorresse em fase mais avançada da vida seria unânime a sua consideração como um dano e a concomitante responsabilização do agente. O que muda neste caso é a delimitação do nexo de causalidade para efeitos dessa responsabilidade.

Por isso, mesmo que o próprio careça de capacidade para aquilatar o seu dano - e exactamente com base nessa incapacidade - poder-se-á entender que o filho tem direito a ser indemnizado (danos patrimoniais) e compensado (danos morais $)^{96}$ pelas condições da sua vida, ainda que não as considere

92 Também assim no acórdão do nosso STJ, e sublinhado por António Pinto MONTEIRO, "STJ, Acórdão de 19 de Junho de $2001 \ldots$.., p. 382.

93 António Pinto MONTEIRO, “STJ, Acórdão de 19 de Junho de 2001...”, p. 382.

Por isso mesmo, talvez seja a própria configuração jurídica do poder paternal a afastar dos pais a legitimidade para exercer um direito de cariz tão pessoal, como acentua Mota Pinto, embora em última instância não lhe repugne que sejam os pais a agir (Paulo Mota PINTO, “Indemnização...", p. 24).

94 É neste argumento que se funda a nossa prudência face a wrongful life actions intentadas pelo próprio, e não porque vislumbremos aqui pretensas aspirações eugénicas, ao contrário do que afirmou a Corte de Cassazione italiana, na decisão n. ${ }^{\circ}$ 14488/2004, de 29 de Julho de 2004.

95 Mota Pinto refere um “padrão contratual de comparação”, constituído pela "pessoa sem malformações e regularmente funcional” (Paulo Mota PINTO, “Indemnização...”, p. 17).

96 Contra a destrinça entre danos morais e patrimoniais neste ensejo, no sentido de apenas permitir o ressarcimento destes últimos, Manuel Carneiro da FRADA, "A Própria Vida como Dano...". 
pessoalmente lesivas ou não tenha capacidade para tal apreciação ${ }^{97}$. O reconhecimento deste dano em nada pactua com a ideia de que existem vidas desvaliosas, mas sim condições de vida que o são ${ }^{98}$, pelo que não há qualquer atentado ao princípio da dignidade humana.

Estamos conscientes de que a admissibilidade da wrongful life action suscita problemas de vária ordem, não só devido à sua complexidade e à dificuldade em calcular a dimensão do dano e a correspondente indemnização (o que não é justificativo suficiente para a sua rejeição, pois o mesmo ocorre noutros casos, como de resto sucede com toda a espécie de danos morais), mas também porque abala muitos dos fundamentos do nosso raciocínio formal. Desde logo há que averiguar se será a responsabilidade civil o mecanismo adequado para prover às necessidades das pessoas com deficiências ou antes os sistemas sociais de compensação ${ }^{99}$.

Os problemas agudizam-se quando a pretensão se dirige contra os pais, pois esta acção pode até ser vista como uma ingerência inadmissível do Estado na vida privada da mulher, ao culpabilizá-la por ter decidido ter o filho ${ }^{100}$, embora nos pareça que à luz do princípio da responsabilidade reprodutiva e dos deveres reprodutivos algumas "ingerências" contam com justificação bastante. Marta Vicente ${ }^{101}$ considera que seria contraditório que o ordenamento jurídico, num primeiro momento, admitisse o aborto, e o remetesse inclusive à esfera de livre decisão da mulher, e depois, num segundo momento, a sancionasse por ter decidido não abortar estando verificados os pressupostos para o fazer. Mas, segundo vemos as coisas, a autora confunde o desaparecimento da tipicidade criminal com a legitimidade jurídica geral da conduta. Ora, são planos que não se identificam, como nos ensina o princípio da unidade da ordem jurídica em sentido unilateral. Veja-se o que se passou com o adultério: não obstante ter deixado de ser um ilícito típico nem por isso desapareceu o juízo de censura cominado pelo direito civil em sede de divórcio. Claro que sempre se pode dizer que o adultério nunca foi juridicamente configurado como um direito, ao passo que o aborto actualmente parece sê-lo nas 10

97 Admitindo uma indemnização ao filho, Paulo Mota PINTO, "Indemnização...", p. 13 ss.

98 Reportamos o nosso juízo unicamente ao dano existente para a própria pessoa, não tomando em conta (porque não devem ser tomados) outros danos por vezes alegados, como sejam o dano para a sociedade, para o Estado e para a própria humanidade (M. J. ALONSO PARREÑO, "Demandas Judiciales...").

99 Sobre os sistemas sociais de compensação, Anastasios MORAITIS, "When Childbirth Becomes Damage...", p. 56, 57. Manuel Carneiro da FRADA ("A Própria Vida como Dano...") distingue entre "dano" e "necessidade", sendo que apenas esta última assiste à criança nascida com a deficiência. Daqui conclui que a solução serão meios assistenciais de natureza solidária-distributiva, e não indemnizações.

100 Marta Nunes VICENTE, “Algumas Reflexões...", p. 137, 140.

${ }^{101}$ Marta Nunes VICENTE, "Algumas Reflexões...", p. 140. 
primeiras semanas. Mas não se descura que o exercício de um direito possa lesar terceiros e, nesta medida, seja o seu titular responsabilizado por tais danos, e bem pode ser o que sucede nesta hipótese.

Outro ponto usualmente considerado na avaliação da legitimidade da wrongful life é a sua necessidade e utilidade. Desde logo, para salvaguarda da posição do filho. Pois uma exclusiva indemnização aos pais por danos patrimoniais colocá-lo-ia sempre na dependência daqueles e, porventura, em carência quando falecessem. É que a indemnização devida aos pais apenas visa salvaguardar a posição destes, não a do filho, a qual deve ser objecto de ponderação autónoma ${ }^{102}$.

Há quem invoque igualmente o argumento da incongruência de atribuir uma indemnização ao filho e não aos pais, quando o facto lesivo é o mesmo e, sobretudo, sendo o filho o principal lesado ${ }^{103}$. Mas, por um lado, um mesmo facto pode ser lesivo para X e não para Y; por outro lado, o filho pode ser o maior lesado de uma perspectiva objectiva e geral, mas subjectivamente podem os pais sentir muito mais a lesão ao filho, sobretudo quando este seja incapaz de se auto-avaliar

Mas mesmo dentro deste apertado condicionalismo devem estes processos ser admitidos com granu salis, sob pena de abrirmos a porta a todo o tipo de pretensões.

Porque não permitir também que o filho processe os pais por estes o terem tido não obstante não estarem de perfeita saúde, ou quando eram já muitos velhos, ou ainda muito novos, ou não terem possibilidades económicas suficientes para lhes proporcionar uma vida melhor, ou, como sucedeu na primeira wrongful life action, por nascer numa família monoparental ${ }^{104}$ ?

Diferentemente, outros casos existem em que a bondade da wrongful life action nos parece mais evidente, como quando os pais têm conhecimento do seu estado de saúde ou da sua predisposição genética e ainda assim decidem ter um filho, sabendo que será, com grande probabilidade, portador da doença, situação que poderia ter sido evitada mediante a selecção de gâmetas (lavagem de esperma, por exemplo), ou quando os pais recusem "tratar" o nascituro mediante terapia génica ou uma intervenção cirúrgica in utero, ou

\footnotetext{
${ }^{102}$ Assim, mal se percebe a decisão do Conseil d'État de 14 de Fevereiro de 2007, que condenou um hospital ao pagamento de uma indemnização sob a forma de renda mensal durante a vida do filho (embora Marta Nunes VICENTE, “Algumas Reflexões...", p. 123) entenda que esta é a única forma de proteger a autodeterminação dos pais).

${ }^{103}$ Paulo Mota PINTO, "Indemnização...”, p. 14/16.

${ }^{104} \mathrm{Ou}$ ainda devido às circunstâncias sociais que rodearam a sua concepção (sobre indemnizações derivadas de crianças nascidas de actos incestuoso, Virginie BONNINGUE, Naissance..., p. 73/80).
} 
ainda quando os pais optam por transferir embriões in vitro que sabem de antemão sofrer de anomalias.

Há ainda que fazer uma distinção entre os embriões in vitro e in utero.

No caso de um embrião uterino, em que os pais devem optar entre prosseguir com aquela gestação ou interrompê-la e assim destruir uma vida, temos sérias dúvidas de que estas acções devam ser admitidas. Embora sejamos partidários da escolha pela não existência (pela eutanásia), parece-nos que daqui não decorre que possamos culpar terceiros pelo facto de existirmos. Esta conclusão vale quer para os casos em que os pais decidem ter a criança apesar de informados do estado do feto, quer, por maioria de razão, para os casos em que nem conhecem o estado do feto por não se ter realizado qualquer diagnóstico prénatal. Ter uma criança não pode ser considerado um acto ilícito para efeitos de qualquer tipo de responsabilidade. Coisa diferente sucede nos casos em que o dano à integridade física é provocado pelos próprios pais (abuso de drogas ou álcool, outros comportamentos de risco), porquanto neste cenário é evidente que devem ser responsabilizados pelos danos assim causados no feto. Todavia, mesmo fora deste particular contexto poderão surgir casos excepcionais que requeiram a responsabilização dos pais: suponha-se que existe a possibilidade de um tratamento uterino e, ainda assim, os pais o recusam. Neste caso, e porque não são confrontados com a hipótese de aborto, cremos que a recusa deve ser avaliada para efeitos de responsabilidade civil (mas não penal, dado que não existe entre nós o delito de ofensa à integridade física da vida uterina).

No caso de embriões in vitro, em que os pais são defrontados com a escolha entre transferir um embrião em boas condições ou um outro em condições mais precárias, pouca justificação tem optar por esta segunda hipótese. É o próprio princípio da beneficência que impõe a transferência do embrião são. É que neste caso sempre haverá embriões que ficarão fora do projecto parental, de modo que não estamos perante o dilema "destruir uma vida ou deixá-la prosseguir", porque necessariamente serão descartadas vidas e é o melhor interesse da pessoa que virá a existir que dita que nasça aquele que terá uma vida sã. Contudo, temos muitas dúvidas que um processo de wrongful life contra os pais que transferiram um embrião doente ou deficiente venha a ser bem sucedido, pelo menos entre nós.

A extrema complexidade e novidade (pelo menos, no nosso ordenamento) das questões discutidas não nos permitem ainda tomar uma posição firme acerca de algumas delas. Limitámo-nos, por isso, a partilhar as reflexões, as possibilidades e as perplexidades que nos suscitam. Não temos a pretensão de oferecer um esclarecimento cabal sobre a resolução dos problemas aqui descritos, mas simplesmente alertar para a litigância que certamente muito em breve chegará aos nossos tribunais. 


\section{Bibliografia}

Abeille, Jean-François. Responsabilité Médicale, in Teboul Gérard dir., Procréation et Droits de l'Enfant. Bruxelles: Bruylant; 2004.

Akazaki, R. Lee. "Wrongful Birth": An Ironic Name for a Cause of Action in the Law of Medical Malpractice [documento on line] 1999 [actualizado 2010 Agosto 20]. Disponivel em http://www.gilbertsondavis.com/site/gilbertson_davis_emerson/assets/ pdf/Wrongful_Birth.pdf

Alonso Parreño, M. J. Demandas Judiciales por Nacimiento con Discapacidad (Wrongful Birth, Wrongful Life): Perspectiva Jurídica [documento on line] [actualizado 2010 Agosto 26]. Disponível em http://www.down21.org/legislacion/temasinteres/demandasjudic/ perspjuiridica.htm

Araújo, Fernando. A Procriação Assistida e o Problema da Santidade da Vida. Coimbra: Almedina; 1999.

Bonningue, Virginie. Naissance Vie Préjudiciables et de L'Enfant au Regard de la Responsabilité Médicale et Parentale [documento on line] 2000/2001, [actualizado 2010 Agosto 31]. Disponível em ]http://faculty.ksu.edu.sa/dr.reda/Documents/\%D8\%A7\%D9\%84\%D9\%8 5\%D9\%83\%D8\%AA\%D8\%A8\%D8\%A9\%20\%D8\%A7\%D9\%84\%D9\%82\%D8\%A7\%D9\% $86 \% \mathrm{D} 9 \% 88 \% \mathrm{D} 9 \% 86 \% \mathrm{D} 9 \% 8 \mathrm{~A} \% \mathrm{D} 8 \% \mathrm{~A} 9 /$ Naissance $\% 20 \mathrm{et} \% 20 \mathrm{vie} \% 20$ prejudiciables $\% 20$ de $\% 201$ 'enfant $\% 20$ au $\% 20$ regard $\% 20 \% 20 \mathrm{de} \% 20$ la $\% 20$ responsabilite $\% 20$ medicale $\% 20$ et\%20parentale.pdf

Brazier, Margaret. Medicine, Patients and the Law. Harmondsworth: Penguin; 1987.

Capen, Karen. New Prenatal Screening Procedures Raise Spectre of More "Wrongful-Birth Claims". Canadian Medical Association Journal, 1995; 152(5).

Carey, Kristen. Wrongful Life and Wrongful Birth: Legal Aspects of Failed Genetic Testing in Oocyte Donation, Penn Bioethics Journal, Vol. I, Issue 1 [documento on line] Spring 2005 [actualizado 2010 Agosto 24] http://www.bioethicsjournal.com/past/pbj1.1_carey.pdf

Chadwick, Ruth; Schroeder, Doris. Applied Ethics (Critical Concepts in Phylosophy). London: Routledge; 2002.

Collins, E. An Overview and Analysis: Prenatal Torts, Preconception Torts, Wrongful Life. Wrongful Death and Wrongful Birth: Time for a New Framework. Journal of Family Law 1983/1984; 22.

Coppens, Philippe. Du préjudice d’être né? in Procréation Médicalement Assistée : Régulation Publique et Enjeux Bioéthique. Bruxelles: Bruylant; 2003.

Cordeiro, António Meneses. Tratado de Direito Civil Português, I, Parte Geral, Tomo III, 2. ${ }^{a}$ edição. Coimbra: Livraria Almedina; 2007.

Cosmi, Ermelano; Mordini E. La Bioetica ed i Diritti del Nascituro, in Scritti in Onore di Guido Gerin. Padova: CEDAM; 1996.

Costa, Amélia. Perspectiva Jurídica de um Acto de Amor - A Procriação Assistida. Lisboa: UAL; 2000.

Costa, José Francisco de Faria. O Fim da Vida e o Direito Penal, in Liber Discipulorum para Jorge de Figueiredo Dias. Coimbra: Coimbra Editora; 2003. 
Costa, José Francisco de Faria. Vida e Morte em Direito Penal (Esquisso de Alguns Problemas e Tentativa de Autonomização de um Novo Bem Jurídico). Revista Portuguesa de Ciência Criminal 2004; 14 (1/2).

Costa, José Francisco de Faria. O Perigo em Direito Penal. Coimbra: Coimbra Editora; 2000.

Cunha, Conceição. Algumas Considerações sobre a Responsabilidade Penal Médica por Omissão, in Liber Discipulorum para Jorge de Figueiredo Dias. Coimbra: Coimbra Editora; 2003.

Dias, João Álvaro. Procriação Assistida e Responsabilidade Médica. Coimbra: Coimbra Editora; 1996.

Dias, Jorge de Figueiredo; Monteiro, Sinde, Responsabilidade Médica em Portugal. Boletim do Ministério da Justiça, n. ${ }^{\circ}$ 332, 1984.

Dickens, Bernard. Canada: The Ontario Law Reform Commission Project on Human Artificial Reproduction, in Law Reform and Human Reproduction. Aldershot, Brookfield USA, Hong Kong, Singapore, Sydney: Dartmouth; 1992.

Dickens, Bernard. Wrongful Birth and Life, Wrongful Death before Birth, and Wrongful Law, in Legal Issues in Human Reproduction. Brookfield USA, Hong Kong, Singapore, Sydney, Dartmouth: Aldershot; 1989.

Dossier de L'institut Européen de Bioétique, La Naissance Handicapée: Un Préjudice Indemnisable? [documento on line] [actualizado 2010 Agosto 25]. Disponível em www. amouretverite.org/.../naissance-handicapee-prejudice-indemnisable.pdf

Dworkin, Roger. Limits - The Role of the Law in Bioethical Decision Making. Bloomington, Indianapolis: Indiana University Press; 1996.

Engelhard, Tristram H. The Foundations of Bioethics. New York, Oxford: Oxford University Press; 1986.

Feinberg, Joel. Harm To Others. New York: Oxford University Press; 1984.

Fidalgo, Sónia. Responsabilidade Penal por Negligência no Exercício da Medicina em Equipa. Coimbra: Coimbra Editora; 2008.

Frada, Manuel Carneiro da. A própria Vida como Dano? Dimensões Civis e Constitucionais de uma Questão-Limite, Revista da Ordem dos Advogados, ano 68, Vol. I [documento on line] 2008 [actualizado 2010 Agosto 30] http://www.oa.pt/Conteudos/Artigos/detalhe_artigo.aspx ?idc $=30777 \&$ idsc $=71981 \& i d a=72382$

Franco, Caiado Guerreiro e Associados. Guia da Responsabilidade dos Médicos [documento on line] [actualizado 2010 Abril 10].

Disponível em www.fcguerreiro.com/GuiadaResponsabilidadedosMedicos.pdf

Glannon, Walter. The Morality of Selective Termination, in Reproduction, Technology and Rights. New Jersey: Humana Press; 1996.

Glover, Jonathan. Future People Disability and Screening" in Bioethics. Oxford Readings in Philosophy. New York: Oxford University Press; 2001.

Goffi, Jean-Yves. La Notion de Vie Préjudiciable et l'Eugénisme, in De l'Eugenisme d'État à l'Eugenisme Privé, Paris, Bruxelles: De Boeck Université; 1999.

Guarneri, Attilio. Nascita del Figlio Malformado, Errore Diagnostico del Medico e Regola di Responsabilità Civile. Rivista de Diritto Civile 2002; XLVIII (6).

Harris, John. Clones, Genes and Immortality. Oxford, New York: Oxford University Press; 1998. 
Hensel, Wendy. The Disabling Impact of Wrongful Birth and Wrongful Life Actions. Harvard Civil Rights-Civil Liberties Law Review 2005; 40.

Heyd, David. Genetics: Moral Issues in the Creation of People. Berkeley: University of California Press; 1992.

Jecker, Nancy. The Ascription of Rights in Wrongful Life Suits. Law and Philosophy 1987; 6(2).

Kasimba, Pascal. IVF Regulation: The Search for a Legal Basis, in Embryo Experimentation - Ethical, Legal and Social Issues. New York, Victoria: Cambridge University Press; 1990.

Lima, Fernando Pires De, Varela João De Matos Antunes, Código Civil Anotado, Vol. I. Coimbra: Coimbra Editora; 1987.

Loureiro, João Carlos. Tomemos a Sério os Direitos do Embrião e do Feto. Cadernos de Bioética 1997; 14.

Mason, Ken. Abortion and the Law, in Legal Issues in Human Reproduction. Aldershot, Brookfield USA, Hong Kong, Singapore, Sydney: Dartmouth; 1989.

Mercer, David. The Wrongful Life Concept: The Role of the Courts in Individual Morality, Inquiry Journal [documento on line] 2006 [actualizado 2010 Agosto 28]. Disponível em http://www.unh.edu/inquiryjournal/06/articles/mercer.html.

Monteiro, António Pinto. Portuguese Case Note. European Review of Private Law 2003; 11(2).

Monteiro, António Pinto. STJ, Acórdão de 19 de Junho de 2001, Direito a Não Nascer?. Revista de Legislação e Jurisprudência 2002; 134, n. 3933.

Monteiro, Fernando Pinto. Direito à Não Existência, Direito a Não Nascer, in Comemorações dos 35 anos do Código Civil e dos 25 Anos de Reforma de 1977 - Vol II - A Parte Geral do Código e a Teoria Geral do Direito Civil. Coimbra: Coimbra Editora; 2007.

Moraitis, Anastasios. When Childbirth Becomes Damage: A Comparative Overview Of "Wrongful Birth" And "Wrongful Life" Claims". Lex Medicinae 2007; 4(8).

Morris, Anne. Saintier Severine, To Be or Not to Be: Is That The Question? Wrongful Life and Misconceptions. Medical Law Review 2003; 11.

Muller, Anne-Claire. L’Affaire Perruche (Débat sur les Dérives vers un Eugénisme Libéral [documento on line] [actualizado 2010 Agosto 20]. Disponível em www.droit-medical. net/IMG/doc/L_affaire_Perruche-ACM.doc

Neville, Warwick. Lokuge Buddhima, Wrongful Life Claims: Dignity, Disability and "A Line in the Sand, The Medical Journal of Australia, 185 (10) [documento on line] 2006 [actualizado 2010 Setembro 4]. Disponível em http://www.mja.com.au/public/ issues/185_10_201106/nev10697_fm.html

Nunes, J. M. Martins. Da Responsabilidade dos Médicos Anestesiologistas [documento on line] [actualizado 2010 Fevereiro 20]. Disponível em www.huc.min- saude.pt/

anestesiologia/.../Responsabilidade_med_Anestes_Dr_JMNunes.pdf

Oliveira, Guilherme de. O Direito do Diagnóstico Pré-Natal, in Temas de Direito da Medicina. Coimbra: Coimbra Editora; 1999.

Oliveira, Vanessa Cardoso. Wrongful Life Action - Comentário ao Acórdão do Supremo Tribunal de Justiça de 19 de Junho de 2001. Lex Medicinae 2004; 1(2).

Ossorio, Pilar. Inheritable Genetic Modifications, in Designing our Descendants. Baltimore, London: The John Hopkins University Press; 2003.

Osuna, Eduardo; Raposo, Vera Lúcia. Embryo Dignity: The Status and Juridical Protection of the In Vitro Embryo. Medicine and Law 2007; (64). 
Parfit, Derek, Reasons and Persons. Oxford; Clarendon: 1984.

Pedro, Rute Teixeira. A Responsabilidade Civil Do Médico. Coimbra: Coimbra Editora; 2008

Pereira, André Gonçalves. O Consentimento Informado na Relação Médico-Paciente. Coimbra: Coimbra Editora; 2004.

Pinto, Carlos Alberto da Mota. Teoria Geral do Direito Civil, 4. ${ }^{\circ}$ ed. (por António Pinto Monteiro, Paulo da Mota Pinto). Coimbra: Coimbra Editora; 2005.

Pinto, Paulo Mota. Indemnização em Caso de "Nascimento Indevido" e de "Vida Indevida" ("Wrongful Birth" e "Wrongful Life"). Lex Medicinae 2007; 4 (7).

Raposo, Vera Lúcia. O Dilema do Rei Salomão: Conflitos de vontade quanto ao destino dos embriões. Lex Medicinae 2008; 5 (9).

Raposo, Vera Lúcia. O Direito à Vida na Jurisprudência de Estrasburgo. Jurisprudência Constitucional 2009; 19.

Raposo, Vera Lúcia. In the Borderline of Human Reproduction, in Droit de la Santé Publique dans un Contexte Transnational. Bordeaux: Les Études Hospitalières Éditions; 2010.

Rodrigues, Álvaro da Cunha. Reflexões em Torno da Responsabilidade Civil dos Médicos, Direito e Justiça, Vol. XIV, tomo 3, 2000.

Shapira, Amos. Wrongful Life' Lawsuits for Faulty Genetic Counseling: Should the Impaired Newborn be Entitled to Sue?. Journal of Medical Ethics 1998; 24.

Shiffrin, Seana Valentine. Wrongful Life, Procreative Responsibility, and the Significance of Harm. Legal Theory 1999; 5.

Simone, R. Procreazione e Danno: Della Nascita Indesiderata al Diritto alla Scelta. Il Diritto di Famiglia e delle Persone, 2003; XXXII (4).

Sousa, Rabindranath Capelo de. O Direito Geral de Personalidade. Coimbra: Coimbra Editora; 1995.

Steinbock, Bonnie. The Logical Case for "Wrongful Life". Hastings Centre Report 1986; 20.

Stewart, Hamish. Harms, Wrongs, and Set-Backs in Feinberg's Moral Limits of the Criminal Law. Buffalo Criminal Law Review 2001; 5 (47).

Stolker, Carel. Wrongful Life: The Limits of Liability and Beyond. International and Comparative Law Quarterly 1994; 43.

Stretton, Dean. The Birth Torts: Damages for Wrongful Birth and Wrongful Life. Deakin Law Review 2005; 10 (1).

Tarantino, Antonio. Dalla Dichiarazione Universale dei Diritti dell'Uomo all'Identità dell'Embrione Umano, in Bioetica, Coscienza e Libertà - Aspectti Antropologici, Giuridici, Medici e Sociali. Bari: Atti II Congresso Nazionale della Societâ Italiana pela la Bioetica ed i Comitati Etici; 2003.

Vicente, Marta Nunes. Algumas Reflexões sobre as Acções de Wrongful Life: A Jurisprudência Perruche. Lex Medicinae 2009; 6 (11).

Wrongful Birth/Wrongful Life Claims, [document on line] [actualizado 2010 Agosto, 23]. Disponivel em http://www.tresscox.com.au/file/document/resource/32/Wrongful\%20 Birth\%20\&\%20Wrongful\%20Life\%20Claims.pdf 
Resumo: As wrong actions no início da vida (wrongful conception, wrongful birth e wrongful life) e a responsabilidade médica

Com as modernas técnicas de diagnóstico pré-natal é possível detectar as doenças antes do nascimento e mesmo antes da concepção da criança. Por vezes não podemos evitar o nascimento nestas condições, na medida em que ainda não conhecemos um tratamento eficaz, e a única alternativa é interromper a gravidez.

As "wrong actions" destinam-se a responsabilizar os profissionais de saúde que não informaram sobre a existência de uma doença e, inclusivamente, responsabilizar os pais pela sua recusa em abortar não obstante terem conhecimento do estado da criança.

Estaremos perante um novo eugenismo ou da desejada possibilidade de acabar com o sofrimento? Responsabilizar juridicamente pessoas que não provocaram directamente o dano atenta contra o nexo de causalidade ou respeita ainda as suas regras? Será o aborto um direito, uma obrigação, ou qualquer outra coisa? A existência é sempre valiosa ou não importa somente uma dimensão quantitativa e devemos exigir também uma dimensão qualitativa?

Palavras-chave: Wrongful life; wrongful birth; wrongful conception; diagnóstico pré-natal; responsabilidade civil; prejuízo do nascimento.

Summary: The wrong action at the beginning of life (wrongful conception, wrongful birth $e$ wrongful life) and medical liability

With the modern techniques of pre-natal diagnosis is possible to detect maladies before birth and even before the child conception. Sometimes we aren't able to avoid a birth in these conditions, since we are still unaware of a successful treatment, and the only alternative is to interrupt the pregnancy.

The "wrong actions" are aimed to act against the health professionals that have not informed about the existence of a disease and even to act against the parents because they refused to abort, even though they knew about the child's condition.

Is this a new eugenics or the desired possibility of abolishing pain? To impose juridical liability on people that has not caused directly the damage goes against the causal connection or does it still respect their rules? Is abortion a right or a duty, or is it something else? Is existence always a value or it is not sufficient a quantitative dimension and we must also demand a qualitative dimension?

Key-words: Wrongful life; wrongful birth; wrongful conception; pre-natal diagnosis; civil liability; damage of birth.

Résumé: Les wrong actions au début de la vie (wrongful conception, wrongful birth et wrongful life) et la responsabilité médicale

Avec les modernes techniques de diagnostique prénatal est possible détecter des maladies avant la naissance et même avant la conception de l'enfant. Quelquefois on ne peut pas 
éviter la naissance dans ses conditions, parce que nous ne connaissons pas encore un traitement efficace et la seule alternative est interrompre la grossesse.

Les «wrong actions» sont destinées à responsabiliser les professionnels de santé que n'ont pas informé de l'existence d'une maladie et, quand même, de responsabiliser les parents pour leur refus d'avorter bien qu'ils aient connaissance de l'état de l'enfant.

Sera-t-il un nouveau eugénisme ou la désirée possibilité de exterminer la douleur? Responsabiliser juridiquement personnes que n'ont pas provoqué directement le dommage viole le lien de causalité juridique ou respect encore ses règles? Sera l'avortement un droit, ou une obligation, ou quelqu'une autre chose? L'existence est toujours précieuse ou on doit demander aussi une dimension qualitative au delà d'une dimension quantitative?

Mots-clés: Wrongful life; wrongful birth; wrongful conception; diagnostique prénatal; responsabilité civile; préjudice-naissance.

\section{Pedido de separatas:}

VERA LÚCIA RAPOSO

vir@vda.pt 